\title{
Institutionalizing The Rights Of Mental Patients: Committing The Legislature
}

\author{
Grant H. Morris* \\ [It] must be remembered that legislatures are ultimate guardians of \\ the liberties and welfare of the people in quite as great a degree as \\ the courts. ${ }^{1}$
}

\section{INTRODUCTION}

In 1961, the American Bar Foundation reported on its study of the rights of the mentally ill im a book entitled The Mentally Disabled and the Law. ${ }^{2}$ Chapter Five of that book deals specifically with "Rights of Hospitalized Patients."3 After an extensive review of existing legislation, the editors concluded: "Statutes by and large do not deal adequately with the problem of patients' rights."

In 1971, the American Bar Foundation produced a revised edition of its study, ${ }^{5}$ which may be viewed as a 10 -year progress report. The new edition was justified on three grounds: (1) "pervasive attention [has been] focused during the sixties upon the plight of the mentally ill;"' (2) the final report of the Jomt Commission on Mental Illness and Health provided a "critical evaluation of our nation's response to the needs of its mentally ill ... ;" and (3) "by and large the states have responded to the challenges in that report by instituting new programs and enacting laws and procedures for their implementation." " This programatic and legislative activity has not been directed primarily at securing rights for the institutionalized mentally ill. Rather, the focus has been on avoiding institutionalization of

* Professor of Law, University of San Diego. B.A. 1962, J.D. 1964, Syracuse University; LI.M. 1971, Harvard Law School.

1. Missouri, K. \& T. Ry. v. May, 194 U.S. 267, 270 (1904) (Holmes, J.).

2. American Bar Foundation, The Mentally Disabled and the Law (F. Lindman \& D. McIntyre eds. 1961) [hereinafter cited as 1961 BAR REPORT].

3. Id. at $142-82$.

4. Id. at 155 .

5. Amlatcan Bar foundation, The Mentally Disabled and the Law (rev. ed., S. Brakel \& R. Rock eds. 1971) [hereinafter cited as 1971 BAR REPORT].

6. Id. at xiii.

r. Ia.

8. Ita. 
the mentally ill by providing treatınent within community-based centers. ${ }^{9}$ Despite a slight change in language, the conclusion of the revised Chapter Five remained the same: "Statutes by and large do not adequately protect the rights of patients who have been hospitalized."10

This Article will discuss existing patients' rights legislative models and a proposed new model, suggesting deficiencies in each and recommending modifications for future legislative reform. It is my contention that greater protection of patient freedom within the institution can be achieved through legislation and that such protection is desirable. Today, advances in treatment of the mentally ill can be used to support traditional societal assumptions that maximization of individual liberty is an important goal.

II

\section{TOWARdS A PROPER BaLANCE}

It is axiomatic that mental health statutes are concerned with the interrelationship of patients and the institutions and personnel that serve those patients. Of necessity, these statutes determine the rights and responsibilities of each. Statutes which designate all mental patients to be incapable of retaining or exercising any "rights" are surely archaic. However, even today it is foolhardy to advocate complete retention of all rights by all patients. Even the most fervent of civil libertarians recognizes the need to strike a balance between liberty and health when the two are in conflict. ${ }^{11}$

Among the probleins in formulating a legislative package of patients' rights is the developinent of procedures to be utilized to determine when a right should be circumscribed or lost. In formulating such procedures, there are two extreme positions that could be taken. Statutes could be drafted listing the various rights of patients, but then provide that the superintendent may deny any of these rights "for good cause"12 or "in the patient's best interest."13 Such a "pro-administration" position does not really offer protection to patients because the conditions under which their rights may be lost are phrased in such vague terms that administrative discretion is vintually complete. At the other extreme, statutes could be drafted to enumerate im absolute terms

9. See discussion in text accompanying notes 22-28 and 33-41 infra.

10. 1971 BAR REPÓRT, supra note 5, at 171.

11. Ennis, Civil Liberties and Mental Illness, 7 CRIM. L. BuLl. 101, 102 (1971). Mr. Ennis was the Director of the New York American Civil Liberties Union's Special Litigation Project on the Rights of Mental Patients.

12. See, e.g., CAL. Welf. \& INST'NS CODE $\$ 5326$ (West Supp. 1973); MASS. GEN. LAws ch. 123, \& 23 (Supp. 1973).

13. MASS. GEN. LAWS ch. 123, $\$ 23$ (Supp. 1973). 
all rights retained by patients. The statutes could require the superintendent of the institution to petition the court for an order limiting those rights in individual cases if limitation is ever appropriate. Such a "propatient" position would place an unbearable burden on the administration of the state institutions. ${ }^{14}$ The resolution of the tension between these two positions is a critical indication of the effectiveness of any set of patients' rights. ${ }^{15}$

Philosophically, it is easy to defend a position which would constrict the discretionary control exercised by institutional personnel over a inental patient's freedom. Our society places a high value on the worth of the individual as an individual and as an autonomous decision-1naker. ${ }^{16}$ Generally, we recognize his freedom of choice and defer to his judgment, even though "we" as a society might view his choice as contrary to his best interests, as we defme them. Nor is his individuality, his choice, his liberty ${ }^{17}$ to be sacrificed without significant ceremony ${ }^{18}$ upon the altars of societal progress "we" liave constructed.

However justifiable institutionalization is in the individual case, institutionalization itself is the very antithesis of personal identity and individual autonomy. Erving Goffman, in his classic work, ${ }^{19}$ and others ${ }^{20}$ have attested to the repressive qualities of institutions and their effect on inmates. From the moment he enters the institution, the individual "begins a series of abasements, degradations, humiliations, and profanations of self. His self is systematically, if often unintentionally, mortified."21 A person who is institutionalized is,

14. There are two institutional considerations:

(1) "Effective treatment, in many instances, necessitates a withdrawal of certain patient rights." 1971 BAR REPORT, supra note 5, at 155.

(2) The administrative problems of running a public mental institution are enormous, and recommendations that would impose administrative constraints should be clearly warranted. Id.

15. The American Bar Foundation asserted that "[t]he crux of the problem [of providing for patients' rights] may be primarily the extent to which discretion to control the patient's freedom should be vested in the hands of hospital authorities." Id.

16. See, e.g., U.S. DECLARATION OF INDEPENDENCE:

We hold these truths to be self-evident, that all men are created equal, that they are endowed by their Creator with certam unalienable Rights, that among these are Life, Liberty, and the pursuit of Happimess. . . .

17. See, e.g., U.S. CoNST. ainend. I-X; XIII; XIV, § 1.

18. See, e.g., U.S. CoNST. amend. V; XIV, § 1.

19. E. Goffman, AsYLums (1961).

20. See, e.g., D. Vall, Dehumantzation and the Institutional Career (1966); Glass, The Future of Large Public Mental Hospitals, 16 Mental Hospitals 9 (1965).

21. GofFMAN, supra note 19, at 14. "The low position of inmates relative to their station on the outside, established initially through the stripping processes, creates a milieu of personal failure in which one's fall from grace is continually pressed home." Id. at 66-67. 
by that fact alone, deprived of more than freedom of movement. He is subjected to the process of depersonalization. Only an approach which minimizes this intrusion upholds the concept of individuality.

David L. Chambers, in a seminal work, ${ }^{22}$ articulated the justifications for requiring courts to search for the least restrictive alternative to civil commitment of the mentally ill and to refrain from ordering institutionalization when a less drastic means will achieve the state's purpose. Arguing that civil commitment involves severe infrimgements of constitutionally protected fundamental liberties, Professor Chambers analogized to cases in which the Supreme Court has upheld the principle of the least restrictive alternative. ${ }^{23}$ Specifically, in invalidating legislation as overbroad, the Court relied upon the fundamental liberties of travel (freedom of movement) in Aptheker v. Secretary of State ${ }^{24}$ and Shapiro $v$. Thompson, ${ }^{25}$ and association in Shelton v. Tucker. ${ }^{28}$ In Shelton, Mr. Justice Stewart wrote: "In a series of decisions this Court las held that, even though the governmental purpose be legitimate and substantial, that purpose cannot be pursued by means that broadly stifle fundamental personal liberties when the end can be more narrowly achieved."27 Similarly, it lias been argued that the high value society attaches to freedom from pliysical confinement necessitates a search for the least restrictive alternative to civil commitment. ${ }^{28}$

Application of the "least restrictive alternative" rule should not be limited to the decision whether institutionalization of the individual can be avoided. Individuals for whom there is no less restrictive alternative than confinement itself should not be deprived of the right to the least restrictive conditions of confmement within the institution. The fact of confmement means that societal purposes have prevailed over the individual's fundamental personal liberties; thus, one should be especially solicitous of the remaining rights retained or retainable by the individual himself. ${ }^{29}$

22. Chambers, Alternatives to Civil Commitment of the Mentally lll: Practical Guides and Constitutional Imperatives, 70 MrCH. L. REv. 1107 (1972).

23. Id. at 1145-51.

24. 378 U.S. 500 (1964).

25. 394 U.S. 618 (1969).

26. 364 U.S. 479 (1960).

27. 1 d. at 488 .

28. Chambers, supra note 22, at 1155-68. See In re Ballay, 482 F.2d 648 (D.C. Cir. 1973), in which the court held that before an individual can be civilly committed, it inust be proven beyond a reasonable doubt that he meets the criteria for such commitment. The court relied on the "one overwhelming similarity" between the civil model and the criminal model to justify the imposition of the criminal standard of proof: "the result of successful prosecution may be loss of liberty, frequently in its most absolute sense through confinement." $1 d$. at 657.

29. If anything, the deprivation of liberty on a noncriminal, nonpunishment 
The idea of scrutinizing the conditions under which mental patients are confined in an effort to safeguard their remaining liberties has received some judicial recognition. In Covington v. Harris, ${ }^{30}$ the Court of Appeals for the District of Columbia Circuit held that a civil patient, confined in the maximum security ward of St. Elizabeth's Hospital as dangerously mentally ill, could properly petition the court by a writ of habeas corpus to obtain a transfer to a less restrictive ward within the same hospital. Chief Judge Bazelon, writing the opinion of the court, stated:

The principle of the least restrictive alternative is equally applicable to alternate dispositions within a mental hospital. It makes little sense to guard zealously against the possibility of unwarranted deprivations [of liberty] prior to hospitalization, only to abandon the watch once the patient disappears behind hospital doors. The range of possible dispositions of a mentally ill person within a hospital, from maximum security to outpatient status, is almost as wide as that of dispositions without. The commitment statute no more authorizes unnecessary restrictions within the former range than it does within the latter. ${ }^{31}$

Admittedly, Covington involved the appropriateness of more secure physical confinement and thus the holding follows in a natural continuum from the basic principle itself. However, the case lends support to the assertion of a broader right: that confinement shall not act to deprive the patient of any right unless necessary to achieve the legitimate purposes of the order of commitment itself. ${ }^{32}$

The ennergence of a legal argument for the least restrictive alternative to hospitalization has been paralleled, and to some extent preceded, by the energence of the community mental health treatment concept.

Primarily responsible for the developinent of the community mental health concept has been the widely perceived fact that the large state mental hospitals provided a very inadequate answer to the problems of the mentally disabled in this country. Although they

basis demands that he be compensated while in the position of societally-inflicted disability by weighing the balance more heavily in his favor when his other rights are subject to jeopardization.

30. 419 F.2d 617 (D.C. Cir. 1969).

31. Id. at 623-24 (emphasis in original).

32. In Wyatt v. Stickney, 344 F. Supp. 373 (M.D. Ala. 1972), appeal docketed sub. nom. Wyatt v. Aderholt, No. 72-2634, 5th Cir., Aug. 1, 1972, the court declared: "Patients have a right to the least restrictive conditions necessary to achieve the purposes of commitment." Id. at 379 . It is unclear whether the court was referring only to physical conditions or to all conditions of confinement. It is arguable that the more comprehensive right was meant to be conferred, in that the court's declaration is but one of a series of "rights" stated to be required for a humane psychological and physical environment. See discussion in text accompanying notes 155-59 infra. 
are not meant to replace the state mental hospitals, community mental health centers-the operational components of the conceptwould work to make the alternatives to long-term institutionalization more realistic and increase their utilization. ${ }^{33}$

The 1961 report of the Joint Commission on Mental Illness and Health recommended the development of locally-based clinics and services to move the focus of treatment of mental illness from the isolated institution to the community. In 1963, Congress responded by enacting the Community Mental Health Centers Act. ${ }^{34}$ This legislation "represents the first instance of significant federal aid and intervention in the mental health area, and constitutes the first program specifically directed at local community services." ${ }^{35}$ To be eligible for participation in the federally funded program, states must adopt an approved state plan. Community mental health centers requesting federal financial support must conform to the state plan and provide five federally imposed "essential" elements of service-inpatient, outpatient, partial hospitalization, energency, and consultationeducation services. ${ }^{36}$

The community mental health movement is a response to defects in the institutional treatment inodel both in theory and in practical application. Overcrowding and understaffing witlin the institutions, plus physical isolation of the imstitutions themselves, are obvious problems inhibiting successful institutional treatment. ${ }^{37}$ Significant problems also lie beneath the surface. For example, Goffman cites "[t] he handling of many human needs by the bureaucratic organization of whole blocks of people"38 as a key fact of institutional life which results in a basic split between the managed group (mental patients) and their managers (attendants and other treating personnel). ${ }^{30}$ Dehumanization is the end product.

Psychiatric inpatients tend naturally to view those caring for them as powerful, controlling figures, whether they are benevolent or malevolent. Staff members similarly tend to dehumanize patients, especi-

33. 1971 Bar Report, supra note 5, at 8-9. A "Community Mental Health Services Act" was first enacted in New York in 1954 to encourage the establishment of local treatment clinics. Ch. 10, $\$ 1$, [1954] N.Y. Sess. Laws. As amended, these statutes appear as N.Y. MENT. HYG. LAw $\$ \$ 11.01-33$ (McKinney Supp. 1973).

34. Pub. L. No. 88-164, tit. II, 77 Stat. 290 , as amended, 42 U.S.C. $\$ \$ 2681-87$ (1973).

35. 1971 BAR REPORT, supra note 5 , at 10.

36. Id. at 11. Additionally, there are five nonmandatory but "desirable" services: diagnostic, rehabilitative, pre- and after-care services, training programs, and research and evaluation programs. Id.

37. See discussion and sources cited in Chambers, supra note 22, at 1112-13, 1125-26.

38. GofFman, supra note 19 , at 6 .

39. Id. at 7 . 
ally since they must often inflict or recommend distasteful or painful psychological or physical procedures. Such factors push both staff and patients toward withdrawal into subgroupings with separate values and internally shared role experiences. ${ }^{40}$

In this environment, the potential for abuse existent in the exercise of attendants' discretionary power becomes a reality. ${ }^{41}$

It would be too easy to write off the public mental hospitals as outmoded, obsolete relics of the past. These dinosaurs are not extinct. They are currently a way of life, and in the future will continue to be a way of life, for hundreds of thousands of human beings. The promise of community mental liealth has yet to be fulfilled.42 Quantitatively and qualitatively, existing cominunity mental health programs fail to provide the broad range of services contemplated and are unable to cope with patient intake. ${ }^{43}$

In its most recent Position Statement on Community Mental Health Centers, the American Psychiatric Association calls for the integration of services among community mental health centers and public and private psychiatric hospitals. Far from abandoning public mental hospitals, the Association declares their role to be one of active treatment and rehabilitation.

A key responsibility of the centers is to assist in the development of active treatment and rehabilitation programs in psychiatric hospitals, to obviate the need for hospitalization whenever possible, and to assume immediate responsibility for services to patients who have been hospitalized and have returned to the community. This purpose would be ill served if the centers were to cope only with the acute or most highly treatable patients and were to transfer the least treatable patients to public mental hospitals; doing this would tend to concentrate a treatment-oriented staff in the former and a custodially oriented staff in the latter. Instead, the centers and hospitals both need to be treatment oriented; there must be a choice between them for any given patient, based on differential diagnosis and differing clinical needs. A range of models for effecting liaison between the centers and public mental hospitals should be established. ${ }^{44}$

40. Almond, Keniston, \& Boltax, Patient Value Change in Milieu Therapy, 20 ArCh. OF GeN. Psychintry 339, 350 (1969).

41. "I have records of patients who were beaten by staff for the sin of having initiated verbal conduct. During my own experience, for example, one patient was beaten in the presence of other patients for having approached an attendant and told him, 'I like you.'" Rosenhan, On Being Sane in Insane Places, 13 Santa Clara LAw. 379, 394 (1973). For other examples of abusive conduct of staff and depersonalization of patients, see id. at 394-96; Ferleger, Loosing the Chains: In-Hospital Civil Liberties of Mental Patients, 13 SANTA CLARA LAw. 447, 456-57 (1973).

42. 1971 BAR REPORT, supra note 5, at 10-13.

43. Id. at 10. See generally sources cited in 1971 BAR REPORT, supra note 5, at 10, n.48.

44. American Psychiatric Association, Official Actions: Position Statement on Community Mental Health Centers, 130 AM. J. PsychiatRY 239 (1973). 
The public mental hospital is viewed as the appropriate resource for providing centralized and specialized long-term inpatient services for one or more community centers. To achieve this result, "long-term care" must cease being a euphemism for "custodial care."45 There is growing recognition that mental hospitals can no longer remain warehouses for individuals viewed as untreatable. Mental institutions must reverse the present priorities by which they service society as their primary client rather than the inental patient. ${ }^{46}$

Community mental health is not the only treatment innovation that has occurred within the last 20 years. New psychotherapeutic approaches to the treatment of the institutionalized mentally ill have been developed as well. The introduction of tranquilizing and other psyclioactive drugs in the mid-1950's has been cited as eliminating the necessity of permanent institutionalization for most patients. ${ }^{47}$ Hospitals have reexperimented ${ }^{48}$ successfully in converting locked wards into open wards. ${ }^{49}$ Voluntary admissions to mental hospitals are be-

45. Ozarin \& Levenson, The Future of the Public Mental Hospital, 125 AM. J. PSYCHIATRY 1647, 1651 (1969).

46. See, e.g., Suchotliff, Steinfeld, \& Tolchin, The Struggle for Patients' Rights in a State Hospital, 54 MeNT. HYG. 230, 234 (1970).

47. The United States Department of Health, Education, and Welfare has reported:

The drugs are easy to administer and achieve results without intermediary convulsions or coma. They do not cure mental illness, but relieve symptoms so that other methods of therapy can be applied to previously disturbed patients. Tranquilizers calm the agitated, hostile patient to the extent that physical restraints and seclusion are rarely needed. Antidepressants lift the patient's mood and increase his awareness, enabling him to cope with common emotional problems with less difficulty. Although there are some side effects, in most instances they are considered annoying rather than harmful. Clinical tests have revealed that complications arising from the use of the drugs are rarely serious if the drugs are properly administered. Through the use of drug therapy, many patients who had been hospitalized on a custodial basis can now receive outpatient treatment and be restored to a useful hife in the community.

U.S. Department of Health, Education, and Welfare, Mental Illness and its Treatment 14 (1965). See also U.S. Department of Health, Education, and Welfare, The Comprehensive Community Mental health Center 6-7 (1964); Hearings on the Constitutional Rights of the Mentally Ill Before the Subcomm. on Constitutional Rights of the Senate Comm. on the Judiciary, 91st Cong. 1st \& 2nd Sess. at 314-15 (1970) (statement of Dr. Roger Egeberg) [hereinafter cited as 1970 Hearings!.

48. The "open-door" policy is not a recent innovation. See generally 43 AM. J. INSANITY 181-203 (1886) (discussion of the policy as utilized by progressive hospitals of the nineteenth century).

49. Hurst, The Unlocking of Wards in Mental Hospitals, 114 AM. J. PsychinTRY 306 (1957); Koltes, Mental Hospitals with Open Doors, 113 AM. J. PsYchinTRY 250 (1956); Snow, Open Ward Policy at St. Lawrence State Hospital, 115 AM. J. PsYCHIATRY 779 (1959). See also Hearings on the Constitutional Rights of the Mentally Ill Before the Subcomm. on Constitutional Rights of the Senate Comm. on the Judlciary, 87th Cong. 1st Sess., pt. 1, at 45 (1961) (statement of Albert Deutsch) [hereinafter cited as 1961 Hearings]. 
ing encouraged. ${ }^{50}$

These treatment developinents support increased patient liberty within the institutions theinselves. For example, the elimination of dehumanization is recognized as an "essential prerequisite"51 to treatment in a mental hospital. This requires that each patient be genuinely respected as a human being. ${ }^{52}$ As explained by a former superintendent of St. Elizabeth's Hospital:

In this regard, it should be recognized that each patient has specified rights and privileges. He has the right to be addressed and regarded in the same respectful and noncondescending or nonpatronizing manner as do his healthy peers. He should be clothed and groomed in such a way that he would not have cause to be ashamed of his appearance were he not ill. He has the right to a place where he may have some privacy for himself, certain of his possessions, and the time necessary to develop and exercise his capacity for independent and responsible behavior. Finally, he should be allowed to maintain and nurture useful contacts between himself and the other patients and nembers of the community, while receiving from these individuals sufficient reaction to his behavior, thinking, and feelings to enable him to have that information which is necessary to develop a realistic self-appraisal..$^{53}$

There is a realization that the goal of treatment is not adaptation to continued confinement, but alleviation, if not elimination, of the reason hospitalization was ordered in the first place. ${ }^{54}$ The processes of depersonalization do not provide "useful attitudes or habits of response for living in the "real world." "'55

Stated simply, programs have been devised to "deinstitutionalize" the imstitutions. ${ }^{56}$ Whether denominated "milieu therapy," "therapeu-

50. 1970 Hearings, supra note 47 , at 13 (statement of Zigmond M. Lebensohn, M.D.) and 322 (statement of Dr. Sherman Kiefer). Some states have established the policy by statute. For example, New York law provides:

It shall be the duty of all state and local officers having duties to perform relating to the mentally ill to encourage any person suitable therefor and in need of care and treatment for mental illness to apply for admission as a voluntary or informal patient.

N.Y. MENT. HYG. LAW $\$ 31.21$ (a) (McKinney Supp. 1973).

51. Glass, supra note 20, at 18.

52. Cameron, Nonmedical Judgment of Medical Matters, 57 GEO. L.J. 716, 731-32 (1969); Ozarm, Moral Treatment and the Mental Hospital, 111 AM. J. PsYCHIATRY 371 (1954). "Here is a point at which the values of democracy, rehion and medicine agree-the value and dignity of the imdividual. . . ." Id. at 378 .

53. Cameron, supra note 52, at 732.

54. Tucker \& Maxmen, The Practice of Hospital Psychiatry: A Formulation, 130 AM. J. PsychintRy 887, 889 (1973).

55. Rosenhan, supra note 41 , at 398 .

56. As Drs. Tncker and Maxmen explain:

In the design of a hospital program it is also essential to create an atmosphere that encourages patients to take active responsibility for themselves and 
tic community," "patient government," or whether unnamed, these therapies have become widely accepted in the last decade. ${ }^{57}$ They have even been utilized successfully with chronic patients. ${ }^{68}$ These treatment programs are more than mere attempts to elimmate abuses in the treatment of mental patients. They seek to restore dignity in patients, not as patients, but as responsible individuals. The role of the patient is not to exhibit "sick" behavior, but to exhibit normal behavior to the extent possible.59 Additionally, the hospital seeks "to approximate the kind of living conditions found in the usual everyday life of people at large." 60

Obviously, a recogmition of imcreased patient liberty is an intrinsic part of these therapies. For example, one therapeutic community experiment began with the issuance of the following instructions to the staff: "1. no form of mechamical restraint was to be used on the ward; 2 . the use of the seclusion room was to be discontinued; 3 . the barbituates were to be administered only under unusual circumtances." 61 Freedom from mechanical restraimts, seclusion, and excessive medication are patients' "rights" which the law has yet to protect fully. These and other patients' rights have been and are being supported within the mental institutions, not because courts or legislatures have inposed them, but because enlightened treating personnel have viewed them as essential components of treatment. Assertions that the greater

\begin{abstract}
others. In other words, instead of being the passive recipients of the staff's therapeutic efforts, the patients sbould assume the role of change agents. In this manner they are able to raise their already lowered self-esteem, counteract their regressive tendency, and realize that they still possess assets during a period of their lives when their failures would seem to predominate. Thus patient governments or simply involving patients in decisions about their own care and the care of others may be a positive influence, not because "democracy cures mental illness" or "psychopathology is caused by a lack of egalitarianism in our society," but rather because they can encourage and restore the patient's optimal social functioning.
\end{abstract}

Tucker \& Maxmen, supra note 54, at 889. See generally M. Jones, The TherApeutic Community (1953); Abroms, Defining Milieu Therapy, 21 ARch. OF GEN. Psychiatry 553 (1969). But cf. Wexler \& Scoville, The Administration of Psychiatric Justice: Theory and Practice in Arizona, 13 ARIz. L. REv. 1, 217-18 (1971) (suggesting overly restrictive decisionmaking by patient governments).

57. Almond, Keniston, \& Boltax, The Value System of a Milieu Therapy Unit, 19 ARCH. OF GeN. PsXchiatry 545 (1968); Tucker \& Maxmen, supra note 54, at 888. But see Bartz, Loy, \& Cook, Mental Hospitals and the Winds of Change, 55 MeNr. HYG. 266 (1971) (suggesting that locked wards and controlled environments will be encountered as mental hospitals are sent the long-term, marginal-adjustment problem patients who are undesirable treatment prospects in the community).

58. Ellsworth, Reinforcement Therapy With Chronic Patients, 20 HosP. \& COMMUNITY PSYCHIATRY 238 (1969).

59. Wilmer, Toward a Definition of the Therapeutic Community, 114 AM. J. PSYCHIATRY 824, 832 (1958).

60. Ozarin, supra note 52, at 377.

61 . Wilmer, supra note 59 , at 829 . 
protection of patients' rights implied by these therapies make them too expensive, impractical or unwarranted appear to be spurious.

\section{III}

\section{EXISTING Legislative ModeLs}

Innovations in treatment of the institutionalized mentally ill generally have not been reflected in enlightened new legislation. The laws in many states still picture the mental patient as one who is likely to be permanently confined im an institution and who is and will contimue to be devoid of all ability to comprehend or exercise any rights. ${ }^{22}$ In a real sense, the law is responsible for the contimuing stigmatization of the mentally disabled.

In opening a Senate subcommittee hearing on "Constitutional Rights of the Mentally Ill," Senator Sam Ervin decried "legislative lethargy" ${ }^{33}$ which deprives individuals "of their right to health and to effective exercise of their freedom . . .." Similar complaints have been expressed in numerous books and articles. ${ }^{65}$ Although legislative reform has been advocated, specific new legislation itself has rarely been articulated. ${ }^{66}$ Rather, writers prefer to analyze existing case law in order to propound an expansion of patients' rights on a Constitutional basis. ${ }^{67}$

62. In North Carolina, the notorized certificate of the superintendent of a state hospital for the insane declaring a person confined therein to be "of insane mind and memory or mentally retarded" shall be sufficient evidence for the clerk of the superior court to appoint a guardian. N.C. GEN. STAT. § 35-3 (1966).

West Virgimia law provides, in part: "The entry of an order ordering hospitalization for an indeterninate period shall relieve the patient of legal capacity." W. VA. CODE $\$ 27-5-4$ (Supp. 1973).

Wisconsin law provides: "Hospitalization under this chapter, whether by voluntary admission or cominitunent ... raises a rebuttable or disputable presumption of incompetency while the patient is under the jurisdiction of hospital authorities." Wrs. STAT. 51.005(2) (1957) (einphasis added).

63. 1970 Hearings, supra note 47 , at 1 .

64. $I d$.

65. See, e.g., B. Enns, The Rights of Mental Patients 93 (1973); Comment, Compulsory Commitment: The Rights of the Incarcerated Mentally Ill, 1969 Duxe L.J. 677, 698 (1969); Note, Conditioning and Other Technologies Used to "Treat?" "Rehabilitate?" "Demolish?" Prisoners and Mental Patients, 45 S. CaL. L. Rev. 616, 618, 646-47, 681 (1972); Note, The Rights of the Mentally Ill During Incarceration: The Developing Law, 25 U. FLA. L. REv. 494, 517 (1973).

66. For example, of the authorities cited in note 65 supra, only one contains a draft of a proposed patients' rights statute. Note, The Rights of the Mentally IIl During Incarceration: The Developing Law, supra note 63, at 519-20. A new "Right of Communication" statute is suggested. There are no legislative proposals for other patients' rights discussed in the article.

67. See, e.g., Ferleger, supra note 41; Case Comment, Wyatt v. Stickney and The Right of Civilly Committed Mental Patients to Adequate Treatment, 86 HARv. L. REv. 1282 (1973). 
Nevertheless, if one compares the statutory tables on rights of mental patients contained in the American Bar Foundation's report of $1961^{68}$ with the tables contained in the revised report of $1971,^{60}$ the amount of legislative activity encountered is surprising. In October, $1959,{ }^{70}$ only 33 jurisdictions ${ }^{71}$ had a statutory provision on the subject of patient correspondence. ${ }^{72}$ By October, $1969,{ }^{73}$ the number had risen ${ }^{74}$ to $41 . .^{75}$ In October, 1959 , only 20 states had a statutory provision on visitation of patients. ${ }^{76}$ By October, 1969, the number had risen to $32 . .^{77}$ In October, 1959, only 12 jurisdictions statutorily regulated use of mechamical restraints. ${ }^{78}$ By October, 1969, the number had risen to $25 .^{70}$ In October, 1959, only eight jurisdictions required a diagnostic examination of patients at the time of their admission and 11 required periodic medical examinations. ${ }^{80}$ By Ootober, 1969, the nuber had risen to 11 and 21 respectively. ${ }^{81}$ These data suggest that legislatures are willing to enact patients' rights legislation.

The Interstate Compact on Mental Health establishes cooperative machinery for transferring mental patients between contracting states. $^{\mathbf{8 2}}$ Contracting states agree that "the necessity of and desirability for furnishing . . . care and treatment bears no primary relation to the residence or citizenship of the patient ...."\$3 In deciding whether a patient should be transferred, patient welfare is recognized as being of parainount importance. ${ }^{84}$ The Interstate Compact was

68. 1961 BAR REPORT, supra note 2, at 158-82.

69. 1971 BAR REPORT, supra note 5, at 174-206.

70. A cutoff date of October 1959 was established for the preparation of tables for the original American Bar Foundation Report. 1961 BAR REPORT, supra note 2, at 5 .

71. There were 49 jurisdictions included in the tables-the 48 statcs plus the District of Columbia.

72. 1961 BAR REPORT, supra note 2, at 158-62.

73. A cutoff date of October 1969 was established for the preparation of tables for the revised American Bar Foundation Report. 1971 BAR REPORT, supra note 5, at xix.

74. There were 51 jurisdictions included in the tables-the 50 states plus the District of Columbia.

75. 1971 BAR REPORT, supra note 5, at 174-79.

76. 1961 BAR REPORT, supra note 2, at 158-62.

77. 1971 BAR REPORT, supra note 5, at 174-79.

78. 1961 BAR REPORT, supra note 2, at 163-64.

79. 1971 BAR REPORT, supra note 5, at 180-81.

80. 1961 BAR REPORT, supra note 2 , at 166 .

81. 1971 BAR REPORT, supra note 5, at 184-85.

82. Council of State Governments, Suggested State Legislation, ProGRAM FOR 1958, at 72 (1957). See 1971 BAR REPORT, supra note 5, at 170 (discussion of the historical development of the Interstate Compact on Mental Health). 1973).

83. See, e.g., N.Y. Ment. HYG. LAW \& 67.07 (Article I) (McKinney Supp.

84. Id. 
drafted in the mid-1950's, and by October, 1959, 11 jurisdictions had adopted it. $^{85}$ By October, 1969, the number had risen to $34 .{ }^{86}$ These figures may be particularly significant. The rapid acceptance of the Compact intimates that legislatures will nove quickly to enact patients' rights legislation if a good model is proposed. ${ }^{87}$ If "legislative lethargy" exists, it consists not in an unwillingness to enact patients' rights legislation, but in the desire or capacity to develop an improved legislative model.

In recent years, many states have patterned their patients' rights legislation on one of two models. The first was prepared in the Federal Security Agency by the National Institute of Mental Health and the Office of the General Counsel. Entitled "A Draft Act Governing Hospitalization of the Mentally Ill" [heremafter Draft Act], ${ }^{88}$ it has been reprinted as an appendix to the 1961 Senate Subcommittee Hearings ${ }^{89}$ and to both the original ${ }^{90}$ and revised ${ }^{91}$ Bar Foundation Reports. The Draft Act has been cited ${ }^{22}$ as the originator of an approach which preserves certain civil and medical rights for the patient. ${ }^{93}$

85. 1961 BAR REPORT, supra note 2, at 175-78.

86. 1971 BAR REPORT, supra note 5, at 196-201.

87. The Interstate Compact on Mental Health alleviates to some extent the residency requirements for treatment which have been imposed in some jurisdictions. In Vaughen v. Bower, 313 F. Supp. 37 (D. Ariz.), aff'd, 400 U.S. 884 (1970), a threejudge court held unconstitutional an Arizona statute which authorized the state hospital superintendent to return nonresident patients to the state of their residence. Relying on Shapiro v. Thompson, 394 U.S. 618 (1969) (residency requirements affecting eligibility to receive welfare benefits held unconstitutional), the court ruled that the statute created an invidious classification which penalized the right to travel in the absence of a compelling state interest. The court was not persuaded by defendant's argument that the superintendent was not required by the statute to return patients to the state of their previous residence and that his discretionary authority had been exercised benevolently in the best iuterests of the patient. $313 \mathrm{~F}$. Supp. at 42 . It is probleinatic whether the court relied on the widespread acceptance of the Interstate Compact on Mental Health as proof that a residence requirement for the admission of patients into mental facilities does not serve a compelling state interest. Cf. 1971 BAR REPORT, supra note 5, at 171.

88. National Institute of Mental Health, Federal Securtty Agency, A Draft Act Governing Hospitalization of the Mentally Ill (Public Health Service Pub. N. 51, rev. ed. 1952) [hereinafter cited as DRAFT Acr].

89. 1961 Hearings, supra note 49, at 501-43.

90. 1961 BAR REPORT, supra note 2, at 397-416.

91. 1971 BAR REPORT, supra note 5, at 454-73.

92. Comment, supra note 65 , at 700.

93. An examination of the October 1969 statistics of the revised American Bar Foundation Report reveals the influence of the Draft Act on state legislatures. Fourteen of the 33 jurisdictions which had enacted a statutory provision on patient correspondence and 14 of the 32 jurisdictions which had enacted a statutory provision on visitation of patients, based their legislation on the Draft Act. 1971 BAR REPORT, supra note 5 , at 178 n.1, 2. Fifteen of the 25 state statutes regulating use of mechanical restraints were rephicas of the Draft Act provision. $1 d$. at 181 n.1. The Draft Act's requirement of periodic medical examinations every six months was adopted by 10 of the 
The second model of patients' rights legislation is the District of Columbia Hospitalization of the Mentally Ill Act [hereinafter District of Columbia Act]. ${ }^{94}$ The District of Columbia Act has been termed "the most important of recent mental health codes" be because of "the national character of the enactimg body and the depth of the research involved in its preparation." ${ }^{.96}$ At the time of its enactment, Senator Ervin predicted that the District of Columbia Act would be a model for the states as they revised their mental health statutes, and he has expressed his thankfulness that time has fulfilled his hopes. ${ }^{97}$

There are at least three major deficiencies in the two models and in legislation cast from these nodels. First, there are nany instances where so-called "patients' rights" statutes protect the institution and institutional prerogatives rather than the individual and the individual's liberty. For example, section 19 of the Draft Act estabhishes every patient's right to "humane care and treatment" and "medical care and treatment in accordance with the highest standards accepted in medical practice,"9s but it conditions the latter on "the extent that facilities, equipment, and personnel are available." which obstensibly protects the patient from use of mechanical restraints, empowers the head of the hospital or his designee to order their use upon his determination that they are "required by the medical needs of the patient."100 Section 21 limits a patient's right to communicate by sealed inail, ${ }^{101}$ to receive visitors, and to exercise all civil rights "to the extent that the head of the hospital determines that it is necessary for the medical welfare of the patient to impose restrictions . . ."102 Section 21-561(b) of the District of Columbia Act authorizes the chief of service to read a patient's mail ${ }^{103}$ before it is delivered to the patient "if ... [ [he] beheves the action is necessary for the medical welfare of the patient who is the intended recipi-

21 states which require periodic examinations. Id. at 184-85. (Three other jurisdictions require medical examinations not less often thau annually, and the remaining eight require them as practicable. Id.)

94. D.C. CODE $\$ \$ 21-501$ to -592 (1973).

95. Comment, supra note 65 , at 700 .

96. Id.

97. 1970 Hearings, supra note 47 , at 4.

98. DRAFT ACT, supra note 88, § 19.

99. Id.

100. Id. at $\$ 20$.

101. The Draft Act, however, prohibits limitations on interference with a patient's right to communicate by sealed mail with the central administration and with the court which ordered his hospitalization. DRAFT ACT, supra note 88, \$ 21(b).

102. DRAFT ACT, supra note $88, \S 21$ (a). Additionally, by statute a patient's rights are "[s]ubject to the general rules and regulations of the hospital. . . ." Id.

103. However, a patient retains the right to receive uncensored mail from his attorney or personal physician. D.C. CODE $\$ 21-561$ (a) (1) (1973). 
ent"104 and to have mail he deems unacceptable returned to the sender. ${ }^{105}$

Second, the legislative models are too vaguely worded to prescribe "rights" meaningfully. For example, there are two "right to treatment" provisions in section 19 of the Draft Act. There is an unconditional right "to humane care and treatment"106 and a right "to medical care and treatment in accordance with the highest standards accepted in medical practice," ${ }^{107}$ conditioned on the availability of facilities, equipment and personnel. Does the word "treatment" when first used refer solely to nonmedical "treatment"? Or does it limit the condition expressed when the word "treatment" is used a second time in a inedical context-is the institution still required to provide "humane" medical treatment even though it is excused froin adhering to the highest standards accepted in medical practice because facilities, equipment and personnel are not available? If this is the implication of the language, can inedical treatment that is not in accordance with the highest standards accepted in medical practice be appropriately denominated as "humane treatment"? Neither the stuatutory language nor the commentary to the Draft $\mathrm{Act}^{108}$ provides any answers to these questions.

Section 21-562 of the District of Columbia Code provides simply, "A person hospitalized in a public hospital for mental illness shall, during his hospitalization, be entitled to medical and psychiatric care and treatment."109 Does this statute establish a right, as required by the Court of Appeals for the District of Columbia Circuit in Rouse v. Cameron, ${ }^{110}$ to suitable and adequate treatment for the particular individual in the light of existing medical knowledge? Is the right satisfied, as indicated by the Court of Appeals for the District of Co-

104. D.C. CODE § 21-561(b) (1973).

105. Id.

106. DRAFT ACT, supra note 88, § 19.

107. Id.

108. The commentary to the Draft Act is appended to the Act itself. The commentary to section 19 appears to be directed solely at the second use of the word "treatment" in the draft statute:

The right prescribed by this section states a practical ideal for the care and treatment of mental patients. While demanding adherence to the highest medical standards, it takes account of limitations on facilities, equipment, and personnel which often make adherence to those standards difficult or impossible.

DRAFT ACT, supra note 88, at 32. There is no indication of whether the impossibility of adhering to the highest medical standards, which satisfies the patient's conditional right to treatment, also justifies something less than what seemingly is the patient's absolute right "to humane care and treatment."

109. D.C. CoDE \& 21-562 (1973).

110. 373 F.2d 451,456 (D.C. Cir. 1966). 
Iumbia Circuit in Tribby v. Cameron, ${ }^{111}$ by treatment which is selected by a reasonable and permissible decision on the part of the hospital within a broad range of discretion? Does a conscious medical decision to provide any treatment, a standard articulated by Judge, now Chief Justice, Warren E. Burger, concurring in Dobson v. Cameron, ${ }^{112}$ satisfy the right? Or is some other standard of treatment required-for example, "effective" treatment, "curative" treatment, "responsible" treatment? ${ }^{113}$ The vagueness of this statutory language has provided neither a definitive answer to these questions, nor sufficient guidance to the courts in arriving at an answer.

What is meant by the term "necessary for the medical welfare of the patient"114 for which censorship of mail and communications can be imposed under the District of Columbia Act ${ }^{115}$ or for which restrictions on communication, visitation and all civil rights can be ordered under the Draft Act? ${ }^{116}$ What is meant by the term "required by the medical needs of the patient"117 for which mechanical restraints may be applied to a patient under section 20 of the Draft Act? No answers to these difficult and important questions are provided by the two major legislative models.

Third, both the Draft Act and the District of Columbia Act are silent concerning inany important rights of patients. Although a generalized "right" to receive treatment is prescribed in the Draft Act and the District of Colunibia Act, excesses in institutional choice of treatment are not proscribed. There are no statutory limitations on psychosurgery, experimental research, or hazardous procedures.

The Draft Act contains no statutory limitations on institutional control of a patient's property in the absence of an adjudication of incompetency and the appointment of a guardian. The failure to deal with the subject is based on the assumption of the Draft Act authors that questions of hospitalization should be separated from questions of guardianship. ${ }^{118}$ While separation of the issues may be laudable,

111. 379 F.2d 104, 105 (D.C. Cir. 1967).

112. 383 F.2d 519, 523 (D.C. Cir. 1967). See Marschall, A Critique of the "Right to Treatment" Approach, in G. MORRIS, THE MENTALLY ILL AND THE RIOHT To TREATMENT 49-54 (1970) (discussion of judicial difficulties in formulating a practical standard of treatment).

113. See cases and articles cited in Schwitzgebel, Right to Treatment for the Mentally Disabled: The Need for Realistic Standards and Objective Criteria, 8 HaRv. Crv. Lib.-Civ. Riahrs L. Rev. 513, 519-20 (1973).

114. DrafT ACT, supra note 88, § 21(a); D.C. CODE \$ 21-561 (1973).

115. D.C. CODE $\$ 21-561$ (1973).

116. DraFT ACT, supra note 88, \$ 21(a).

117. DRAFT ACT, supra note 88, § 20.

118. "[T]he determination that hospitalization is justified should be separated from the adjudication of incompetency and the appointment of a guardian. It is a 
complete neglect of all guardianship issues after separation is not. In practice, many hospitals exercise some degree of control over all their patients' property, regardless of whether individual patients have been adjudicated incompetent or not. ${ }^{119}$ Nevertheless, 32 states and the District of Columbia ${ }^{120}$ lack statutory provisions on the subject.

Neither the Draft Act nor the District of Columbia Act contains legislation concerning patient labor. There are no provisions specifying whether employing patients in various work assignments is limited by therapeutic considerations in each individual's case, or whether such employinent is ever justified on a completely nontherapeutic basis. ${ }^{121}$ Limitations on the institution's authority to order patients to work and the effect of a patient's refusal to perform labor are not mandated. ${ }^{122}$ There are no indications of the circumstances, if any, which entitle working patients to be paid or the amounts to be paid. ${ }^{123} \mathrm{~Pa}-$ tients' rights legislation should deal with and resolve these matters.

Most significantly, neither legislative model articulates the extent of a mental patient's power to challenge the abridgement of any right. Stated abstractly, anyone can sue to enjoin arbitrary administrative action that infringes on his rights or, in a reverse situation, can sue to mandamus administrative action to secure what is justly his. These principles, however, are difficult to apply and, in claims involving patients' rights, have rarely been applied. In large measure, this difficulty is attributable to the failure of existing legislation to demarcate the existence and extent of patients' rights and concomitant limitations on hospital authority.

In recent years, some states have enacted patients' rights legislation that has moved thein beyond the two legislative models discussed above. The newly-revised mental health code of California has been described as the "Magna Carta of the inentally ill."124 Section

fundamental theory of the Act that an order of hospitalization decides no more than the questiou of hospitalization." DRAFT ACT, supra note 88, at 2.

119. 1971 BAR REPORT, supra note 5, at 167.

120. Id. at 186-87. The District of Columbia statute provides that a hospitalized patient may not, by reason of the hospitalization, be denied the right to dispose of property, unless he has been adjudicated incompetent. There is, however, no provision regarding the patient's right to retain custody and control of his property, or the institution's authority to assume custody and control or even to exclude certain property from the institution. D.C. CoDe $\$ 21-564$ (a) (1973).

121. See Jobson v. Henne, 355 F.2d 129 (2d Cir. 1966); Wyatt v. Stickney, 344 F. Supp. 373 (M.D. Ala. 1972), appeal docketed sub nom. Wyatt v. Aderholt, No. 72-2634, 5th Cir., Aug. 1, 1972.

122. See Henry v. Ciccone, 315 F. Supp. 889 (W.D. Mo. 1970); Parks v. Ciccone, 281 F. Supp. 805 (W.D. Mo. 1968); Johnston v. Ciccone, 260 F. Supp. 553 (W.D. Mo. 1966); Tyler v. Harris, 226 F. Supp. 852 (W.D. Mo. 1964).

123. See cases cited in note 121 supra.

124. 1970 Hearings, supra note 47, at 316 (Statement of Dr. Roger Egeberg). 
5325 of that Code enumerates the following to be a mental patient's rights:

(a) To wear his own clothes; to keep and use his own personal possessions including his toilet articles; and to keep and be allowed to spend a reasonable sum of his own money for canteen expenses and small purchases.

(b) To have access to individual storage space for his private use.

(c) To see visitors each day.

(d) To have reasonable access to telephones both to make and receive confidential calls.

(e) To have ready access to letter writing materials, including stamps, and to mail and receive unopened correspondence.

(f) To refuse shock treatment.

(g) To refuse lobotomy.

(h) Other rights, as specified by regulation. ${ }^{125}$

Unfortunately, this expansive proclamation of "rights" is contracted into a "mini carta" by section 5326, which provides: "A person's rights under section 5325 may be denied for good cause only by the professional person in charge of the facility or his designee."120

The Massachusetts legislation emulates that of California-announcing the rights of communication and visitation, but restricting or denying these rights on the superintendent's decision that such limitation is in the patient's "best interest." ${ }^{127}$ Other rights are specifically extended to the patient, subject to withdrawal "for good cause by the superintendent or his designee . . . ."128

The North Carolina "loss-of-rights" standard is somewhat more specific. Instead of a "good cause" denial of rights, the North Carolina statute authorizes the imposition of restrictions "to the extent that the chief medical officer of the hospital determmes that it is necessary for the medical welfare of the patient . . . ."12n

In 1973, the State of Washington enacted imto law the California list of patients' rights, ${ }^{130}$ with minor modifications. ${ }^{131}$ These rights,

125. CAL. Welf. \& INST'NS CODE $\S 5325$ (West Supp. 1973).

126. Id. $\$ 5326$ (West Supp. 1973).

127. Mass. Gen. Laws ch. 123, \& 23 (Supp. 1973).

128. Id.

129. N.C. Gen. Stat. § 122-46 (1964).

130. WASH. REv. CODE $\$ 71.05 .370$ (1974 Supp.) (effective January 1, 1974).

131. The Washington statute requires a court order for shock treatment or nonemergency surgery in the absence of consent of the patient. WASH. REv. CODE $\$ 71.05 .370(7)$ (1974 Supp.). The California statute simply gives the patient the right to refuse shock treatmeut, CAL. WeLF. \& INST'NS CODE \& 5325(f) (West Supp. 1973), subject to a "good cause" general denial of such right by the person in charge of the facility or his designee. CAL. WeLf. \& INST'NS CODE $\S 5326$ (West Supp. 1973). 
however, were granted only "[i]nsofar as imminent danger to the individual or others is not created . . .."132 There is no indication as to who makes the determination of imminent danger, what evidence is considered, and the patient's right, if any, to contest the decision.

The New York legislation is more detailed in its articulation of various rights. Nevertheless, such important matters as the right to care and treatment, ${ }^{133}$ communication and visitation, ${ }^{134}$ and custody of a patient's personal property ${ }^{135}$ are declared to be "subject to regulations of the commissioner [of Mental Hygiene]."

It is not my purpose to scrutinize the nuances in language of existing state legislation to determine whether ineaningful distinctions can be drawn between them. Nor will I simply call for increased attention to this problem area and suggest that others attempt the difficult task of creating a new framework for legislative action. Rather, I will put forward and examine the patients' rights proposals of the Michigan Legislative Committee to Revise the Mental Health Statutes [hereinafter "Legislative Committee"] which are now awaiting action by the Michigan Legislature. ${ }^{136}$ As Legal Counsel to this committee, I helped formulate policy resulting in these legislative proposals. Sometimes my ideas carried the day; at other times they did not. Now in my capacity as "ivory-tower" professor, I can criticize the proposals for failing to protect patients adequately. ${ }^{137}$ However, although I am not totally satisfied with the final product, the Michigan proposals tend to alleviate the deficiencies of the model codes discussed above: overprotection of the institution, vagueness, and silence. In a

The Washington statute authorizes the patient " $[t] \circ$ dispose of property and sign contracts unless such person has been adjudicated an incompetent in a court proceeding directed to that particular issue. ..." WASH. REv. CODE $\$ 71.05 .370(8)$ (1974 Supp.).

132. WASH. REV. CODE $\$ 71.05 .370$ (Supp. 1974).

133. N.Y. MENT. Hyg. LAW $\S 15.03$ (McKinney Supp. 1973).

134. Id. at $\S 15.05$.

135. Id. at $\$ 15.07$.

136. In 1969, the Michigan Legislature, in a one-line budget item, appropriated funds "to revise mental health statutes." No. 133, § 1 [1969] Mich. Pub. Acts. To pursue the statutory revision, the Legislative Council, a bipartisan 14-member group of Michigan legislative leaders, created the Michigan Legislative Cominittee to Revise the Mental Health Statutes. The Legislative Committee's recommendations were introduced into the Michigan Legislature as H.B. 5684, Mich. (1974).

On July 14, 1974, after this article was completed, but before it was published, the Michigan Legislature passed a revised H.B. 5684. No. 258 [1974] Mich. Pub. Acts Mich. CoMp. LAws ANN. $\$ \$ 330.1001-.2106$. As enacted, the legislation differs from the Legislative Committee's patieuts' rights proposals in only a few areas. These significant modifications are reprinted in notes 176, 192, 192.1, 200.1, 214.1, infra.

137. I do not attempt to analyze the political constraints which may make unattainable the adoption of legislation $I$ view as philosophically more desirable. In light of political realities, I believe the proposals made by the Legislative Committee are sound and renarkably progressive. 
small but significant step, the proposed statutes specify with greater precision the conditions necessary for limiting or withdrawing rights of patients. Although considerable administrative discretion remains, the ability of the patient to contest abusive exercise of discretion is enhanced.

\section{IV}

\section{The Proposals of the Michigan Legislative Committee to Revise the Mental Health Statutes}

\section{A. General Statutory Provisions}

E. Gordon Yudashkin, M. D., Director of the Michigan Departinent of Mental Health, recently wrote of the importance of cultivating and nurturing dignity and self-respect of patients within mental health facilities. He listed several methods used to personalize services and humanize relationships.

Among other things .... [the facilities] don't line up patients, herd them together, boss them and embarrass them. Chairs and benches have been pulled away from the walls. Furniture has been rearranged to form natural dividers for a variety of day room activities. Wards have been redecorated in sonething other than institution green, and patients have been perınitted to decorate their own bedrooms. . . .

Whenever possible patients should have privacy and freedom. The opportunity to make choices and take independent action is essential to developing self-assurance and realizing one's greatest potential. ${ }^{138}$

These words should be applauded and the efforts strongly supported. There is little, however, that legislation can do to aid those developments. It would be virtually impossible to suggest in a statute that patients should not be herded together, that furniture should be rearranged, or that walls should be painted cheerful colors.

Nevertheless, a statute could and should be enacted to proclaim that a mentally ill person does not lose his rights or privileges merely because he is currently receiving treatinent for his mental illness in the community or in a hospital, as a voluntary or involuntary mental patient. Similarly a person who has at one time received treatment for mental illness should not lose his rights or privileges due to his prior condition. Discrimination based on former mental disability or institutionalization may be as invidious as discrimmation based on race, creed,

138. Yudashkin, Current Diagnosis, 1 Mrch. Dep'T of Mental Health LINK 3 (May 6, 1971). After this article was completed, but before it was published, Dr. Yudashkin resigned his position as director. 
or sex. No person should be dissuaded from obtaining prompt treatment for an existing mental disability by a fear, currently justified, ${ }^{133}$ that his mental disability will continue to haunt him in later years through unwarranted restrictions on his activities.

The legislation should also declare that the specific "patients" rights enumerated in the Mental Health Code are additions to, and not replacements for, the rights of patients as individuals. Legislative intent that patients' rights statutes be construed to protect and promote basic human dignity should be revealed. Such language may assist courts in deciding the difficult questions of when patients' rights have been improperly infringed upon or demed. As a group, these "policy proclamations" should also help eliminate some of the stigma which the public attaches to mental illness. ${ }^{140}$ Furthermore, the statutes would support and encourage efforts by the Department of Mental Health to cultivate im the treating personnel within the institutions an enlightened attitude toward the mentally ill.

\section{The Legislative Committee has proposed:}

Sec. 702. The receipt of mental health services, a determination that a person meets the criteria of a person requiring treatment or for judicial admission, or any form of admission to a facility ${ }^{141}$ including by judicial order:

(a) Shall not operate to deprive any person of his rights, benefits, or privileges.

(b) Shall not cause the person to be deemed legally incompetent.

(c) Does not constitute a determination or adjudication that the person is insane, feebleminded, imbecilic, or idiotic as those

139. Ennis, supra note 11, at 123-24. A New York statute prohibited deprivation of civil rights of individuals who had been voluntarily hospitalized in the past. N.Y. Sess. Laws 1964, ch. 738, $§ 3$. Mr. Ennis asserted that the law had not worked. He suggested that employers should be forbidden by statute to ask a job applicant if he has ever been hospitalized or treated for mental illness. The most recent New York legislation prohibits deprivation of civil rights based on the sole criterion of "receipt of services for a mental disability." N.Y. MENT. HYG. LAW $\$ 15.01$ (McKinney Supp. 1973). While ostensibly extending protection to involuntary mental patients, the revised statute does not address itself to Mr. Ennis' complaint and does not adopt his proposal.

140. See, e.g., In re Ballay, 482 F.2d 648 (D.C. Cir. 1973). The court discussed the stigma which the general public associates with involuntary civil commitment itself and with the "mental illness" label that generally continues even after discharge from the institution. Additionally, the patient's perception of the situation was viewed as significant. Social ostracism is magnified and the patient may demean himself. Id. at 668-69.

141. Section 700 (c) of the proposed legislation provides:

"Facility" means a residential facility which provides mental health services, and which is licensed by the state or is operated by or under contract with a public agency. 
terms are used in other statutes, including but not limited to statutes governing marriage and statutes governing professional, occupational, and vehicle operator's licenses.

Sec. 704. (1) In addition to the rights, benefits, and privileges guaranteed by other provisions of law, the constitution of 1963, and the Constitution of the United States, a recipient ${ }^{142}$ of inental health services shall have the rights guaranteed by this chapter.

(2) The rights enumerated in this chapter shall not be construed to replace or limit any other rights, benefits, or privileges of a recipient of services.

(3) The provisions of this chapter shall be construed to protect and promote the basic human dignity to which a recipient of services is entitled. ${ }^{143}$

Sec. 706. Recipients of mental health services shall be notified by the providers of those services of the rights guaranteed by this chapter. Notice may be accomplished by prominently posting a copy of this chapter or an accurate suminary thereof, by distributing a booklet, or by similar methods. ${ }^{144}$

Critique: Proposed section 702 does not establish appropriate cri-

142. Section 700(e) of the proposed legislation provides:

"Recipient" means a person who receives mental health services from a facility, or a person who receives mental health services from an entity other than a facility which is operated by or under contract with the department or a county community mental health program.

143. The phrase "to which a recipient of services is entitled" and its placement in the sentence may be confusing. Does the provision mean that mental patients are entitled to basic human dignity as are all other persons? Or can the statute be construed to limit the patient's right to human dignity to that amount to which mental patients are entitled as patients? A better wording of the statute would be: "Recipients are entitled to the basic human dignity due all persons. The provisions of this Chapter shall be construed to protect and promote human dignity."

144. The commendable purpose of section 706 to notify patients of their rights may be frustrated in individual cases by the statutorily authorized inethods for accomplishing notice. The statute should provide that whenever special problems existe.g., blind patients, illiterate patients, patients conversant in foreign languages onlyreasonable measures, in addition to posting, must be employed to notify each patient.

Chapter 4 of the proposed Mental Health Code deals with civil admission and discharge procedures for the mentally ill. Proposed section 448 requires the hospital director to notify patients, whether admitted by medical certification or by petition, in writing within 12 hours of admission of their rights to an attorney, to an independent medical evaluation, and to a court hearing. The proposed section $448(2)$ then provides:

If the individual is unable to read or understand the written materials, every effort shall be made to explain them to him in a language he understands, and a note of the explanation and by whom made shall be entered into his patient record.

A similar effort should be made to notify patients of their inpatient rights.

See also Part IV C of this Article infra, where it is recommended that personnel of an independent agency-the Mental Patients' Legal Assistance Service-be required to inform and advise all mental patients of their legal rights. 
teria or procedures to determine when and how a mentally ill person, or a formerly mentally ill person, may properly be denied the right, for example, to marry, to obtain or retain a driver's license, or to engage in licensed professional activity. This deficiency should be remedied by creating appropriate standards and procedures for loss of rights and privileges. The Legislative Committee proposal does not even specifically prohibit use of the fact of treatment or institutionalization as evidence of incapacity to exercise rights or of incompetency itself. The statute merely prohibits equating the two concepts. ${ }^{145}$

\section{B. Specific Inpatient Rights}

If enacted, the "policy proclamation" proposals will set a general tone favorable to increased patient freedom and dignity within the institutions. Those proposals, however, do not deal with specific "rights" which inay be or are necessarily affected by institutionalization itself. Conflicts between the state's interests in efficiency, security, and treatment and the patient's interest in exercising rights he would ordinarily enjoy but for institutionalization commonly arise in the mental hospital setting today. The American Bar Foundation studies examined several such situations, ${ }^{146}$ and the Michigan proposals are by and large concerned with the same conflicts. In the remainder of this Article, I will explore the specific problein areas and the proposed solutions. Where appropriate, I will suggest modifications of proposed legislation to achieve what I believe to be inore desirable solutions.

\section{The Right to Treatment}

Within the last 15 years, the concept of a legally enforceable "right to treatment" for institutionalized mental patients has been asserted. ${ }^{147}$ The right to treatment advocates argue that if a inentally ill

145. In the civil admissions and discharge portion of the proposed code, section 489(1) provides:

No determmation that a person requires treatment, no order of court authorjzing hospitalization or alternative treatment, nor any form of admission to a hospital shall give rise to a presumption of, constitute a finding of, or operate as an adjudication of legal incompetence.

Although this statute is somewhat more specific than section 702 , the basic question whether an order of institutionalization or alternative treatment may be used as evidence of legal incompetence remains unanswered.

146. 1971 BAR REPORT, supra note 5, at 155-206; 1961 BAR REPORT, supra note 2 , at $142-82$.

147. Birnbaum, The Right to Treatment, 46 A.B.A.J. 499 (1960) (generally cited as the first article to articulate the legal right). See also Arens, Due Process and the Rights of the Mentally Ill: The Strange Case of Frederick Lynch, 13 CATH. U.L. Rev. 3 (1964); Bassiouni, The Right of the Mentally Ill to Cure and Treatment: Medical Due Process, 15 De Paul L. Rev. 291 (1966); Note, The Nascent Right to Treatment, 53 VA. L. REv. 1134 (1967). 
person has been involuntarily hospitalized by the state because he needs mental treatment, the state lias an obligation to furnish that treatment. Even if the individual has been institutionalized as "dangerous to himself or others" imstead of "in need of care and treatment," the state must attempt to make that confinement as shont as possible by providing adequate treatment, because involuntary confinement has been imposed without a finding of guilt and without rigorous criminal process safeguards. Furthermore, adherents to these tenets would enforce the right to treatment by authorizing confined persons to petition the court for the remedy of release in situations where the state has not fulfilled is treatment obligations.

The right to treatment concept received its nnajor judicial impetus in the landmark case of Rouse v. Cameron. ${ }^{148}$ In that decision, Chief Judge David Bazelon declared that since the purpose of involuntary hospitalization is treatment, not punishment, the hospital has a duty to furnish treatment, and the patient has a legal right to receive that treatment. This right to treatment, said Judge Bazelon, is enforceable by a writ of habeas corpus. He and others have indicated that grave constitutional problems involving due process and cruel and unusual punishment would arise if involuntarily lospitalized persons could be retained in the institution without affording them adequate treatment. ${ }^{149}$

There was strong and immediate criticism of the Rouse decision. The American Psychiatric Association questioned the competence of the courts to determine adequacy of treatment, and in an official policy statement asserted: "The definition of treatment and the appraisal of its adequacy are matters for medical determination." 150 Indeed, judges on the saine circuit as Judge Bazelon had great difficulty in two decisions after Rouse formulating the appropriate treatment standard required by the right. ${ }^{151}$

The method by which a patient raises the issue of adequacy of treatment--through a writ of habeas corpus seeking release from the institution-has also been questioned. The courts, although willing to accept the principle of a right to treatment, appear unwilling to order the drastic remedy of releasing an mdividual whose mental condition meets the statutory requirements for involuntary institutionaliza-

148. 373 F.2d 451 (D.C. Cir. 1966).

149. Bazelon, Rights of Mental Patients to Treatment and Remuneration for Institutional Work-Prior Court Decisions and Legislation, 39 PA. BAR AssN. Q. 534, 544 (1968); Note, Civil Restraint, Mental Illness, and the Right to Treatment, 77 YALE L.J. 87, 97-104 (1967).

150. Council of the American Psychiatric Association, Position Statement on the Question of Adequacy of Treatment, 123 AM. J. PsychiATRY 1458 (1967).

151. See the discussion in text accompanying notes 109-12 supra. 
tion. ${ }^{162}$ Viewing the right in a broader context, one attorney recently wrote:

Habeas corpus appears to be an inadequate vehicle for meaningful reform because even successful litigation will limit relief to one individual. A single patient might be discharged from an institution or begin to receive treatment, but the institution would continue to function basically unchanged..$^{153}$

The Rouse decision was succeeded by Wyatt v. Stickney, ${ }^{154}$ which announced a new judicial approach to the right to treatment. The Wyatt case involved a lawsuit brought on behalf of all patients at one of Alabama's mental hospitals-a class action alleging inadequate treatment. ${ }^{155}$ In March, 1971, Judge Frank M. Johnson determined that the programs of treatment in use at the hospital were scientifically and inedically inadequate and deprived patients of their constitutional rights. The court ordered the defendants to prepare a specific plan whereby appropriate and adequate treatment would be provided to the patients of the hospital. Thus, the court not only accepted the class action approach to the right to treatment, but also announced a constitutional basis for the right.

After reviewing the standards proposed by the parties and by amici, the court issued a decree establishing and ordering the inplementation of standards which were deeined to be medical and constitutional minimums. ${ }^{150}$ Judge Johnson commended those who had submitted briefs amicus curiae, including the American Orthopsychiatric Association, the American Psychological Association, the American Civil Liberties Union, and the American Association on Mental Deficiency. ${ }^{157}$ These groups supplied the expertise necessary for the court to formulate the standards that were ultimately adopted.

The standards ordered by Judge Johnson encompass most aspects

152. In fact, one author reported that no patient has been ordered released by a court on grounds that he was receiving inadequate treatment. Halpern, A Practicing Lawyer Views the Right to Treatment, 57 GEO. L.J. 782, 784 (1969).

153. Drake, Enforcing the Right to Treatment: Wyatt v. Stickney, 10 AM. CRIM. L. Rev. 587, 595 (1972).

154. 344 F. Supp. 373 (M.D. Ala. 1972), enforcing 325 F. Supp. 781 (M.D. Ala. 1971), appeal docketed sub nom., Wyatt v. Aderholdt, No. 72-2634, 5th Cir., Aug. 1, 1972 (treatment of mentally ill); 344 F. Supp. 387 (M.D. Ala. 1972), enforcing 325 F. Supp. 781 (M.D. Ala. 1971), appeal docketed sub nom., Wyatt v. Aderholt, No. 72-2634, 5th Cir., Aug. 1, 1972 (habilitation of mentally retarded). 155. Wyatt v. Stickney, 325 F. Supp. 781 (M.D. Ala. 1971). The court subsequently granted a motion to add as plaintiffs those patients involuntarily confined in the state's other mental hospital and the residents of a state hospital for habilitation of the mentally retarded. Wyatt v. Stickney, 344 F. Supp. 373, 374-75 (M.D. Ala. 1972).

156. Wyatt v. Stickney, 344 F. Supp. 373 (M.D. Ala. 1972); Wyatt v. Stickney, 344 F. Supp. 387 (M.D. Ala. 1972).

157. Wyatt v. Stickney, 344 F. Supp. 373, 375 n.3 (M.D. Ala. 1972). 
of patient life. There are 35 standards for treating the mentally ill designed to establish a humane psychological and physical environment, to provide qualified staff in numbers sufficient to administer adequate treatment, and to ensure individualized treatment plans. There are also 49 standards designed to provide for adequate habilitation of mentally retarded residents. Most of the standards are not niere generalizations of desired goals, but are extremely specific as to their requirements. It should be reiterated that the 84 standards are medical and constitutional minimums. In addition, "the unavailability of neither funds, nor staff and facilities, will justify a default by defendants in the provision of suitable treatment for the mentally ill." 158

The court retained jurisdiction of the case and did not rule out the possibility of affirmative action, including appointment of a master and professional advisory committees to oversee the implementation of the court-ordered standards, if the state did not fulfill its treatment obligations. ${ }^{159}$

Judge Johnson did more than merely recognize a constitutional right to treatment. ${ }^{160} \mathrm{He}$ announced conditions which nust be established within the institutions in order to give meaningful treatment and standards which must be coinplied with in order to accord constitutionally required adequate treatment. The standards iniposed as prerequisites to adequate treatment are phrased in terms of patients' "rights" necessary to ensure dignity to patients as individuals. ${ }^{101}$ Throughout this Article, I will refer to those prerequisites and conipare them with the Michigan proposals.

The decision in Wyatt indicates that some courts are not unwilling to establish the specific paranieters of the right to treatment and to fashion whatever remedies are necessary to ensure compliance with mandated standards. Whether or not legislatures or other courts will agree with the specific standards laid down in Wyatt, at least they will now discuss those standards and modifications of them, rather than merely focus on the abstract existence of a "right to treatment" and the significance of the term "adequacy of treatment."

Judicial activity in response to right to treatment claims has been paralleled by almost complete legislative inactivity on the subject. Al-

158. Id. at 377 .

159. Id. at 376-77.

160. In Burnham v. Dep't of Pub. Health, 349 F. Supp. 1335 (N.D. Ga. 1972), appeal docketed, No. 72-3110, 5th Cir., Oct. 4, 1972, the district court dismissed a class action complaint by patients of Georgia's mental institutions, holding that there is no constitutional right to treatment. Wyatt and Burnham have been consolidated for purposes of appeal.

161. Wyatt v. Stickney, 344 F. Supp. 373, 379-83 (M.D. Ala. 1972) (standards 1-20 of Appendix A to opinion); Wyatt v. Stickney, 344 F. Supp. 387, 399-405 (M.D. Ala. 1972) (standards 15-38 of Appendix A to opinion). 
though Judge Bazelon has admitted that "the legislature can do a better job ... [in creating] specific procedures and institutions to implement the right to treatment," $" 162$ the legislatures in most states have not done a better job; in fact, they have not done the job at all. It may even be asserted that this relinquishment of responsibility necessitates judicial reliance solely on the United States Constitution and justifies "superlegislative" efforts such as those of Judge Johnson in Wyatt. ${ }^{163}$

The most comprehensive right to treatment bill was introduced ${ }^{164}$ and reintroduced (with minor modifications) ${ }^{165}$ in the Pennsylvania Legislature, but it was not enacted. The bill called for the establishment of a Mental Treatment Standards Committee appointed by the Secretary of Public Welfare and composed of a nonadministrator psychiatrist, a nonpsychiatrist physician, a psychiatric social worker, a clinical psychologist, a psychiatrist experienced in mental institution administration, a psychiatric nurse, and the Cominissioner of Mental Health. ${ }^{166}$ The Committee was to prepare and adopt a "Manual of Minimum Standards for Treatment of Mentally Ill in State Mental Institutions." 167 The bill directed the Committee to specify within its standards:

(1) the number of professional and nonprofessional staff per patient population, including the maximum number of patients for each psychiatrist, physician, psychologist, social worker, industrial therapist, nurse, and attendant;

(2) the minimum qualifications for each professional and nonprofessional staff position;

(3) the minimum number of individual consultations between patient and psychiatrist and other professional personnel and the minimum number of hours of such consultations in each 30-day period;

(4) the frequency and extent of general physical examinations,

(5) requirements for the maintenance of individualized treatment plans for each patient, including (i) the initial diagnosis, (ii)

162. Bazelon, supra note 149 , at 544 .

163. See Case Comment, supra note 67, at 1299-1301.

164. S.B. 1274 and H.B. 2118, Pa. Gen. Assembly, 1968 Sess. The full text of these bills is reprinted as an appendix to Halpern, supra note 152, at 811-816.

165. S.B. 158 and S.B. 816, Pa. Gen. Assembly, 1969 Sess. The full text of S.B. 158 is reprinted as Exbibit II in Furman \& Conners, The Pennsylvania Experiment in Due Process, 8 DUQUesne L. Rev. 32, 67-72 (1969).

166. S.B. 158, Pa. Gen. Assembly, 1969 Sess., § 3(a) \& (b).

167. Id. at $\$ 4$. The bill provided that the Commissioner of Mental Health serve on the committee in an advisory capacity only and have no vote in the adoption of minimum mental treatment standards. Id. at $\$ 3(\mathrm{c})$. 
the manner in which the facilities of the particular institution could improve the patient's condition, (iii) the treatment goals, and (iv) the treatment regimen that was planned to accomplish these goals. ${ }^{108}$

The standards promulgated by the Committee were to be "expressed in objective terms so far as possible in order to minimize the necessity for subjective evaluation of departmental and institutional compliance, in judicial review." ${ }^{169}$ The Committee was required to complete its Manual of Minimun Standards within six months of its appointment, and the standards were to go into effect two years from the effective date of the act. ${ }^{170}$ The Committee was periodically to review the minimum standards and was empowered to make such changes as it deemed necessary. ${ }^{171}$

The Pennsylvania bill also specified a patient's legal remedies if he failed to receive the minimum treatment to which he was legally entitled. Elaborate provisions would have established a Patient Treatment Review Board, ${ }^{172}$ the procedures for hearing patient complaints, ${ }^{173}$ the patient's right to appeal to a court, and the dispositions available to the court. ${ }^{174}$

The Michigan proposals on the right to treatment should be evaluated in the context of the historical development outlined above. The Legislative Cominittee has proposed:

Sec. 708. A resident $t^{175}$ is entitled to mental health services suited to his condition and to a safe, sanitary, and humane living environment.

Sec. 710. Prior to or soon after admission each resident shall receive a comprehensive physical and mental examination. Each resident shall be periodically reexamined not less often than annually.

Sec. 712. An individualized written plan of services shall be developed for each resident. The plan shall be kept current and shall be modified when indicated. The person in charge of implementing the plan of services shall be designated in the plan.

Sec. 714. A resident shall be informed of his clinical status and progress at reasonable intervals in a manner appropriate to his clinical condition.

168. Id. at $\S 4(\mathrm{~b})$.

169. Id at $\S 4(\mathrm{~d})$.

170. Id. at $\$ 4(\mathrm{e})$.

171. Id. at $\$ 4(\mathrm{i})$.

172. Id. at $\$ 6$.

173. Id. at $\$ 7$.

174. Id. at $\S 8$.

175. Section 700 (d) of the proposed legislation provides: "Resident' means a person who resides in a facility." 
Proposed section 720 requires a "facility standards report" to be prepared every two years and transmitted by the Department of Mental Health to the Governor. Each report is to indicate whether the facility complies with standards imposed upon it by accrediting agencies and the federal and state governments, and if it does not comply, whether it should attempt to comply. ${ }^{178}$

176. The full text of the proposal is:

Sec. 720. (1) A facility standards report shall be prepared every 2 years for each facility operated by or under contract with the department or a county community mental health program. Each report shall be transmitted by the department to the legislature and the governor.

(2) Each report shall indicate:

(a) Whether the facility is in compliance with the standards pertinent to the facility established by the organization or organizations geuerally recognized as establishing standards for the types of services being provided by the facility.

(b) Whether the facility is in compliance with any standards which are pertinent to the facility and which must be met in order for federal benefits or federal grants to be received.

(c) Whether the facility is in compliance with the standards applicable to the facility which are established by rules or policies of a state agency or by law.

(3) When the facilitv is not in compliance with one or more of the standards described in subsection (2), the report shall indicate the deficiencies which cause the facility not to be in compliance, and the actions necessary for the facility to achieve compliance, unless the report states reasons for the facility not to attempt to achieve compliance.

As used in this proposal and throughout the Chapter on Patients' Rights:

Sec. 700. (a) "Department" means the (Michigan) department of mental health.

(b) "County community mental health prograin" means a program operated by or under contract with a county community mental health board.

There are two other "Patients' Rights" proposals that may be categorized as "right to treatment" proposals:

Sec. 722. (1) A recipient of niental health services shall not be physically, sexually, or otherwise abused.

(2) The governing body of each facitity shall adopt written policies and procedures designed to protect recipients of mental health services from abuse and to prevent the repetition of acts of abuse. The policies and procedures shall nore particularly define abuse, sliall provide a mechanism for discovering instances of abuse and for reviewing all charges of abuse, shall ensure that firm and appropriate disciplinary action is taken against those who have engaged in abuse, and shall contain those additional provisions deemed appropriate by the governing body.

(3) A facility shall cooperate in the prosecution of appropriate crimmal charges against those who have engaged in unlawful abuse.

Sec. 738. A resident shall continue to be entitled to the free pnblic elementary and secondary education that is guaranteed by the constitution of 1963.

As used in this proposal and throughout the Chapter on Patients' Rights:

Sec. 700. (f) "Governing body" means the director of the department for facilities and other entities operated by the department; the county director for facilities and other entities operated by a county community mental health program; or the agency, organization, or person having the primary legal authority over other facilities.

The Michigan Legislature passed two additional "right to treatment" provisions to the Legislative Committee's proposals: 
Critique: The "right to treatment" proposals of the Legislative Committee are inadequate. Section 708 establishes a "bare bones" principle of the right to treatment without the much-needed flesh that courts and commentators have solicited. After declaring the existence of the right itself, legislative judgnent has been waived. The insufficiency of proposed section 708 becomes clear when the section is applied to the civil admissions portion of the proposed Mental Health Code. Proposed section 470 provides:

Prior to ordering the hospitalization of an individual, the court shall inquire into the adequacy of treatment to be provided to the individual by the hospital. Hospitalization shall not be ordered unless the hospital in which the individual is to be hospitalized can provide him with treatment which is adequate and appropriate to his condition.

It seems absurd to expect the committing court to make a knowledgeable judgment on the adequacy of treatment for a prospective patient when the legislature has offcred no guidance in section 708 as to what constitutes adequate and appropriate services for an individual with a particular mental condition.

Similarly, proposed section 712 simply declares that an individualized written plan of services shall be developed, but it says nothing about the details of the plan. Proposed section 720, while requiring a bi-annual "facility standards report," contains no guidehnes for the establishment of these standards.

In my opinion, the vagaries and generalities of the proposals constrict the legislative insight to be injected into important right-to-treatment decisions. Both the legislature and the courts have a role in determining adequacy of treatment-the legislature needs to establish an articulated standard of treatment applicable to all patients, and the courts must ensure that an acceptable level of treatment has been provided in individual cases.

The patient, as an individual and as part of the collective patient body, must be considered in establishing adequate treatment plans. Combining the best features of the Pennsylvania treatment bill and the Wyatt order would achieve the desired result. Thus, an independent Mental Treatment Standards Board should be created by the legislature to prepare mimimuin treatment standards. Such an approach

Sec. 715. If a resident is able to secure the services of a private physician, he shall be allowed to see his physician at any reasonable time.

Sec. 722. (4) Any recipient of mental health services physically, sexually, or otherwise abused shall have a right to pursue injunctive and other appropriate civil relief.

No. 258, [1974] Mich. Pub. Acts. Also, proposed section 704(2) was amended to specifically include "the right to treatment by spiritual means if requested by the patient, or by his uext of kin or guardian." 
seems preferable to a legislative pronouncement of the specific standards, which would freeze treatment levels until the legislature acted again. The Department of Mental Health, as the agency which is required to adhere to the standards in its facilities; should not also be the agency to set the standards. In an analogous situation, the Supreme Court of California recognized that the agency which perfornis the therapeutic function should not be entrusted with notifyimg a patient of his legal rights and explaining them. ${ }^{177}$ The possibility of role conflict is even greater in a "preparation of standards-adherence to standards" situation.

If the legislature does not establish specific standards, it should at least determine which specific areas need standards and require that those standards be formulated in as objective ternis as possible. The Pennsylvania proposal on minimum number and qualifications of staff and frequency and duration of individual consultations and plyysical examinations ${ }^{178}$ is a good exainple of such quantification.

The addition of treatimg personnel to the staffs of inental hospitals may accord inore treatment to all patients but does not, in and of itself, ensure that adequate treatment is provided to any individual patient. ${ }^{179}$ The Wyatt requirements for individualized treatment plans state with particularity items which can be evaluated by courts to determine adequacy of treatment in individual cases:

Each individualized treatment plan shall contain:

a. a statement of the nature of the specific problems and specific needs of the patient;

b. a statement of the least restrictive treatment conditions necessary to achieve the purposes of commitment;

c. a description of intermediate and long-range treatment goals, with a projected timetable for their attainment;

d. a statement and rationale for the plan of treatment for achieving these intermediate and long-range goals;

e. a specification of staff responsibility and a description of proposed staff involvement with the patient in order to attain these treatment goals;

f. criteria for release to less restrictive treatment conditions, and criteria for discharge;

g. a notation of any therapeutic tasks and labor to be performed by the patient. . . . ${ }^{180}$

177. Thorn v. Superior Court, 1 Cal. 3d 666, 675, 464 P.2d 56, 62, 83 Cal. Rptr. 600, 606 (1970).

178. See the discussion in text accompanying note 168 supra.

179. Ennis, supra note 11 , at 125 .

180. Wyatt v. Stickney, 344 F. Supp. 373, 384 (M.D. Ala. 1972). 
I would also suggest that the legislatively prescribed treatment plan include (1) an estimated date for release or discharge of the patient;(2) a description of services to be provided for the patient after release from the hospital; (3) a requirement that treatment plans be reviewed regularly; ${ }^{181}$ and (4) upon review, an assessment of the reasons that any goals or estimated dates contained in a precedimg plan were not met.

Typically, a mental patient receives nore intensive treatment upon initial admission to a mental hospital than after he has remained for a time and has been assigned to a "continued treatment" ward. There is a significantly lower ratio of patients to treating personnel in admissions wards than in continued treatment wards. ${ }^{182}$ The problem is not one of administrators wilfully withholding treatınent to patients who have been institutionalized for a time; rather, the problem is allocating imadequate numbers of treating personnel where they will do the most good. ${ }^{183}$ But if the goal of treatment-rehabilitation of the individual to the extent that he is able to function adequately outside the institution-remains the same, and I believe it should, a patient's need for treatment opportunities does not necessarily decrease when his length of stay mcreases.

Pursuant to the legislation I have proposed, the Mental Treatment Standards Committee would establish minimunn standards to be utilized m admissions and intensive care umits. It would be unrealistic for me

181. Id. Standard 29 of the Wyatt order requires continuous review of each treatment plan and a mental examination of each patient at least every 90 days.

182. The American Psychiatric Association has suggested the following minimum ratios for public mental institutions:

Physicians/No. of patients

Clinical psychologists/No. of patients

Registered nurses/No. of paticnts

Attendants/No. of patients

\begin{tabular}{ccc}
$\begin{array}{c}\text { Admission and } \\
\text { intensive treat- } \\
\text { ment service }\end{array}$ & $\begin{array}{c}\text { Continued } \\
\text { treatment } \\
\text { service }\end{array}$ \\
\cline { 1 - 1 } $\begin{array}{c}1: 30 \\
1: 100\end{array}$ & & $1: 150$ \\
$1: 5$ & & $1: 500$ \\
$1: 4$ & & $1: 6$
\end{tabular}

American Psychiatric Association, Standards for Hospitals and Clinics 43-45 (rev. ed. 1958). The standards are reprinted as Appendix A to Birnbaum, $A$ Rationale for the Right, 57 GEo. L.J. 752, 779 (1969). Quantified staffing standards were not retained when the A.P.A. standards were revised in 1969. See Wexler \& Scoville, supra note 56, at 231-32 n.68 (speculating that Rouse v. Cameron may have prompted the elimination of staffing tables).

183. In discussing existimg treatment within Pennsylvania's mental hospitals, Senator Reibman, a sponsor of the right to treatment bill in that state, wrote:

In reality, a choice is made as to who should not receive care. The members of the profession would rather use the words selection and priority, but what it all boils down to is that the choice is made not to treat these large numbers of chronically ill patients in the mental institutions in this state.

Reibman, Rights of Mental Patients to Treatment and Remuneration for Institutional Work-Pending Mental Legislation, 39 PA. BAR AsSN. Q. 538, 539 (1968). 
to propose that continued treatment wards meet those same standards. Yet, the establishment of "less than minimum standards" to satisfy the treatment requirement for contimued treatment wards would be undesirable. I feel that the proper approach to this problem should take account of three factors.

First, a patient should be retained in an intensive care ward that meets the minimum treatinent standards established by the Mental Treatment Standards Committee until he can be released to the community as sufficiently rehabilitated, or until he has received the maximum benefit from such treatment. A patient should be permitted to allege that he has received the maximum benefit from treatment. ${ }^{184}$

Second, continued confinement of the individual in a mental hospital after lie has received the maximum benefit from treatment cannot be justified on a "need for treatment" basis. ${ }^{185}$ In fact, legislation should declare that custodial care does not constitute "treatment" and is not a mental health service within the meaning the Mental Health Code.

Third, if the mdividual is to remain in custody after he has received the maximum benefit from the mental hospital treatment, there must be some other basis to justify the commitment. A new hearing with the requisite procedural safeguards should be conducted at this time and result in an appropriate placement in a new institutional setup or release.

For example, indefinite commitment of individuals with sociopathic personalities who have not responded to mental hospital treatment can be justified only as preventive detention. If the real basis for the commitment is alleged dangerousness to society and not need for treatment, and if this justification for commitment is socially desirable and legally sufficient, ${ }^{186}$ the individual should have a trial with stringent criminal process safeguards. ${ }^{187}$ The prediction of danger-

184. See Part IV C of this Article infra.

185. In discussing the individual who is untreatable in the present state of medical science, the Court of Appeals for the District of Columbia stated:

Unless the right to treatment be interpreted to include ineffective treatment, an anomaly in itself, the parens patriae rationale would seemingly fail and indeterminate institutionalization would necessarily be a purely custodial function and justifiable only by other considerations. In re Ballay, 482 F.2d 648, 659-60 (D.C. Cir. 1973).

186. It is beyond the scope of this Article to consider whether these nontreatment confinement arrangements are desirable or legal. However, if my suggested approach is utilized, society will be forced to consider this issue, at least as to those individuals who have received the maximum benefit of treatment. The parens patriae promise of "treatment" would no longer justify indefinite commitment of these individuals.

187. In Lessard v. Schmidt, 349 F. Supp. 1078 (E.D. Wis. 1972), vacated and remanded for specificity in the order, $94 \mathrm{~S}$. Ct. 713 (1974), the court examined the consequences of involuntary hospitalization-in particular, the individual's loss of im- 
ousness must be substantiated. If committed, the mdividual should be placed in a detention facility, not a hospital. Similarly, if there is sufficient justification for retaining chronic schizophrenics because of their mability to care for themselves, a new hearing should be required and placement should be in an extended care facility, not a hospital.

\section{The Right to Decline Treatment}

Currently, a person involuntarily committed to a mental hospital is generally considered, by virtue of his status, subject to treatment. ${ }^{188}$ For example, in Whitree $v$. State, ${ }^{180}$ the New York Court of Claims awarded an ex-patient $\$ 300,000$ conipensatory damages in part for wrongful confimenient. The court found that if the patient had received proper and adequate treatment, he would have been released from the state hospital after two years of confinenient, rather than after 12 years. The court was not persuaded by the hospital's assertion that the patient's refusal to take medication justified the hospital's failure to treat him with modern tranquilizing drugs during his stay at the hospital. The court viewed such an argument as "illogical, unprofessional and not consonant with prevailing niedical standards."1so

The rules relating to the administration of treatment by nonmental hospitals are well settled. Except in einergency cases, before a physician administers treatment or performs an operation, he must obtain the consent of the patient, or if the patient is a minor or incompetent, he must obtain the consent of the patient's parent or guardian. In the absence of an adjudication of incoinpetency of a niental patient, these rules should arguably apply to him as well. Winters $v$. Miller ${ }^{191}$ was one of the first cases to adopt this approach, although the precedential value of the case may be minimized by an unusual

portant civil rights-and concluded that stringent criminal process safeguards are required for the initial commitment. See also In re Ballay, 482 F.2d 648 (D.C. Cir. 1973), in which the court held that proof of mental illness and dangerousness in involuntary civil commitment proceedings must be beyond a reasonable doubt.

188. Even California's mental health statutes, which substantially restrict orders of involuntary civil commitment, specify that a person who is committed is subject to treatment. Thus, a person who has been evaluated as a danger to others, or to himself or gravely disabled and who has not accepted voluntary treatment "may be certified for not more than 14 days of involuntary intensive treatment" at a facility equipped and staffed to provide treatment. CAL. WeLF. \& INST'NS CODE $\$ 5250$ (West 1972). At the expiration of the 14-day period of intensive treatment, he "may be confined for further treatment" for additional 90 day periods if he presents an imminent threat of substantial physical harm to others. CAL. Welf. \& INST'NS CODE $§ 5300$ (West 1972), $\$ 5304$ (West Supp. 1974).

189. 56 Misc. $2 d 693,290$ N.Y.S.2d 486 (Ct. Claims 1968).

190. Id. at 707,290 N.Y.S.2d at 501.

191. 446 F.2d 65 (2d Cir.), cert. denied, 404 U.S. 985 (1971). 
fact situation. The plaintiff-patient was a practicing Christian Scientist whose religious views predated any allegations of mental illness and whose mental illness had not altered those views. The court held that plaintiff had a claim under the federal civil rights statutes for damages resulting from forced medication in violation of her right to freedoin of religion under the first amendment. It remains in the realm of speculation whether a right to decline all treatment will be accepted in other cases involving mental patients who have not been adjudicated imcompetent and who object to treatment on other than religious grounds.

There is no definitive answer at present as to a mental patient's right to refuse any and all treatment, ${ }^{192}$ and the legislature is not likely to provide one. Nevertheless, when therapies involve significant danger to the physical or mental well-being of the patient, the legislature can and should forinulate workable principles.

The Legislative Committee has proposed:

Sec. 716. (1) Except as provided in subsections (2) and (3), a recipient of mental health services shall not have surgery performed upon him, nor shall he be the subject of electro-convulsive therapy or of another procedure intended to produce convulsions or coma, unless consent is obtained froun:

(a) The recipient if he is 18 years of age or over and competent to consent.

(b) The guardian of the recipient if the guardian is legally einpowered to execute such a consent.

(c) The parent of the recipient if the recipient is less than 18 years of age.

(2) If the life of a recipient is threatened and there is not time to obtain consent, the procedures listed in subsection (1) inay be performed without consent after the medical necessity for the procedure has been documented and the documentation has been entered into the record of the recipient.

(3) If one of the procedures listed in subsection (1) is deened advisable for a recipient, and if no one ehgible under subsection (1) to give consent can be found after diligent effort, a probate court may upon petition and after hearing, consent to performance of the procedure in lieu of the person eligible to give consent.

192. Institutionalization in and of itself, insofar as it constitutes legitimate milieu therapy, is a treatment which the involuntarily confined patient may not be able to decline. See generally text accompanying notes 56-60 supra, and Note, Conditioning and Other Technologies, supra note 65, at 621-622 (1972).

The Michigan Legislature amended section 704(2) of the Legislative Committee proposals to specifically include "the right to treatment by spiritual means if requested by the patient, or his next of kin or guardian." No. 258, [1974] Mich. Pub. Acts. 
Sec. 718. (1) A recipient of mental health services shall not be the subject of an experimental research project nor of an unusually hazardous procedure unless the requirements of this section are met.

(2) An experimental research project or an unusually hazardous procedure shall be approved and conducted in the manner prescribed by the governimg body of the facility or other entity. The governing body shall adopt in writing procedures for the approval of and guidelines for the conduct of experimental research projects and unusually hazardous procedures.

(3) An unusually hazardous procedure shall not be performed unless consent is obtained from:

(a) The recipient if he is 18 years of age or over and competent to consent.

(b) The guardian of the recipient if the guardian is legally empowered to execute such a consent.

(c) The parent of the recipient if the recipient is less than 18 years of age.

Critique: The Michigan proposals do not adequately safeguard the individual patient's right to decline treatment, nor do they adequately articulate situations which require a patient's consent. For example, proposed sections $716(1)(\mathrm{b})$ and $718(3)(\mathrm{b})$ authorize the guardian of the patient to consent for him if "legally empowered" to consent. Apparently such authority would exist only if the patient were legally incompetent. The statute should clarify this point by providing that the consent of the guardian of the patient may be substituted for the patient's consent only if the patient is mentally incapable of executing a valid-voluntary, informed and expressed-consent. ${ }^{102.1}$

In addition, a general determination of legal incompetency to manage property or personal affairs, often made at time of admission to the hospital, ${ }^{193}$ should not automatically permit substitution of the patient's judgment when the drastic procedures of sections 716 and 718

192.1. The Michigan Legislature added a definition of "consent" to the Legislativo Committee's proposals. As enacted, section $700(\mathrm{~g})$ provides: "'consent' means an agreement in writing executed by the recipient, his guardian if empowercd to execute a consent, or his parent if he is a minor." No. 258, [1974] Mich Pub. Acts. This definition does not resolve the problem raised in the text. The statute does not clarify tho instances when a guardian is "empowered" to consent for the patient.

193. Proposed section 491 provides:

A court in a proceeding in which an individual has been found to require treatment may consider, if a petition has been filed for a declaration of legal imcompetence and the appointment of a guardian, the question of the individual's legal competence and his need for a guardian.

Thus, although the issues of civil commitment and legal incompetence are separated, they may be determined by the same court at the same time under the Legislative Committee proposals. 
are considered. Prior to the surgery, therapy or other procedure, the patient should by statute ${ }^{194}$ have the right and opportunity to contest the necessity of substituting another's judgment for his, or the validity of any consent allegedly obtained from him.

Even if the requisite consent can be obtained, ${ }^{195}$ institutional prerogatives within the Michigan proposals limit the statutory protection of patients. It appears that the proposed legislation would permit surgery, convulsion or coina-producing therapies, experimental research, and unusually hazardous procedures solely on an institutional judgment that they are "advisable."196 The operations, therapies, or procedures requiring consent should only be permitted by order of the patient's physician when no less dangerous ineasures can achieve the necessary and therapeutically desirable result. Prior to its performance, the patient should by statute ${ }^{197}$ have the right and opportunity to contest the necessity to perform any such operation, therapy, or proccdure.

Proposed section 718 contains no definition of the terms "experimental research project" or "ususually hazardous procedure." Arguably, the statutory scheme permits variation in procedures and guidelines from institution to institution. The recent California experience with succinylcholine chloride illustrates the dangers of excessive institutional prerogative in defining experimental research and should serve as a warning to those who draft legislation. ${ }^{198}$

194. See Part IV C of this Article infra.

195. In Kaimowitz v. Department of Mental Health, Civ. No. 73-19434-AW (Cir. Ct., Wayne Co., Mich. 1973), the court prohibited experimental psychosurgery on a patient and questioned the ability of an involuntarily detained mental patient to give a factually informed, legally adequate consent.

Involuntarily conffmed mental patients live in an inherently coercive institutional environment. Indirect and subtle psycliological coercion has profound effect upon the patient population. Involuntarily confined patients cannot reason as equals with the doctors and admimistrators over whether they should undergo psychosurgery. They are not able to voluntarily give informed consent because of the inherent inequality in their position.

Id. at 29 (footnote omitted).

196. Proposed section 716(3) appears to postulate this test.

197. See Part IV C of this Article infra.

198. Succinylcholme chloride (trade name: anectine) is a muscle relaxant that is commonly given in electroconvulsive therapy to prevent bone fractures while the patient, who is unconscious, due to shock, is undergoing convulsions. It is also used as a relaxant in the administration of anesthesia. "It is not recommended for administration to fully conscious patients . . . ." Mackey v. Procunier, 477 F.2d 877, 878 (9th Cir. 1973). Nevertheless, in two California mental institutions, the drug was injected intravenously into fully conscious patients to produce respiratory arrest. The subjects' intercostal muscles and diapliragms were affected and a period of apnea was produced. For 1.5 to 2 minutes of muscle paralysis, the patients, though fully conscious, were not able to breathe. It was hypothesized that fear of this experience would reduce the level of, or eliminate completely, aggressive behavior of the mental patients, whicls served as the basis for use of the procedure in the first instance. These "experiments" were reported in Reimringer, Morgan \& Bramwell, Succinyl- 
choline As A Modifier of Acting-Out Behavior, CliniCal Medicine 28 (July 1970); Mattocks \& Jew, Assessment of an Aversive Treatment Program with Extreme ActingOut Patients in a Psychiatric Facility for Criminal Offenders (unpnblished, undated article from the California Medical Facility).

The issue of informed consent to these "experiments" has been discussed in other articles. See, e.g., Morris, "Criminality" and the Right to Treatment, 36 U. CHI. L. Rev. 784, 798-800 (1969); Scaring the Devil Out, Medical WORLD News 29-30 (Oct. 9, 1970); Note, Conditioning and Other Technologies, supra note 65, at 633-40, 670-73. Additionally, the Court of Appeals for the Ninth Circuit recently reversed the dismissal of a cause of action in which a prisoner alleged that use of the drug in such an experiment without his consent was an infliction of cruel and unusual punishment and constitnted impermissible tinkering with the mental processes. Mackey v. Procunier, 477 F.2d 877 (9th Cir. 1973).

Equally as significant, however, is the claim that the suecinylcholine chloride treatments were "not experimental." Dr. David Owens, a physician who performed some of the treatments, wrote:

To term this treatment adjunct experimental is a semantic error. It is an innovative, empirical treatment which does not violate the guidelines laid down in a product reference published by the company mannfacturing it in the 1970 Physician's Desk Reference, which states on page 614: "Anectine brand Succinylcholime Chloride is indicated for the production of skeletal muscle relaxation during operative and manipulative procedures and in conjunction with electroshock therapy." There is no prohibition of the drug without anesthesia and it is known to be safer when given alone in electroconvulsive treatment.

Written statement of David Owens, M.D., dated October 26, 1970, enclosed in letter from John E. Gorman, M.D., Medical Director, Human Relations Agency, Department of Corrections, State of California, to Ralph M. Obler, M.D., President, Southern California Psychiatric Society, Jan. 11, 1971, a copy of which is on file with the author.

Dr. Sterling W. Morgan, Superintendent of Atascadero State Hospital, echoed the thoughts of Dr. Owens by stating: "Succinylcholine is a standard adjunct to shock treatment. The difference was that we omitted the shock." Scaring the Devil Out, supra, at 30.

Carrying this argument to its logical extreme, presumably one could assert that performing open heart surgery or any other major surgery on fully conscious, unanesthetized patients is not experimental because there is nothing new about the operation itself, even though today it is only performed on unconscious, fully anesthetized patients.

The California experiments with the drug succinylcholine chloride were conducted in apparent violation of Food and Drug Administration regulations governing new drugs for investigational use in human beings. See generally 21 C.F.R. \& 130 (1973). Section 130.1 of those regulations provides in part:

(h) The newness of a drug may arise by reason (among other reasons) of: ....

(4) The newness of use of such drug in diagnosing, curing, mitigating, treatimg, or preventing a disease, or to affect a structure or function of the body, even though such drug is not a new drug when used in another disease or to affect another structure or function of the body.

(5) The newness of a dosage, or method or duration of administration or application, or other condition of use prescribed, recommended, or suggested in the labeling of such drug, even though such drug when used in other dosage, or other method or duration of administration of application, or different condition, is not a new drug.

Id. Officials at the California Medical Facility and Atascadero State Hospital apparently did not request FDA approval for these programs because they did not believe their uses of anectine were "experimental." But proof that FDA approval should 
The treating personnel of the institutions should be authorized neither to define the terms nor to establish procedures and guidelines for experimental research projects and unusually hazardous procedures. If a Mental Treatment Standards Committee is established, it may also be the appropriate body to examine various therapies and determine which ones constitute experimental research or unusually hazardous procedures for which consent is required by proposed section 718 .

Indeed, I believe that fall hazardous procedures should require patient consent, not just those denoninated "unusually" hazardous. Thus, the Comnnittee should determine what constitutes a hazardous procedure and expand the circumstances requiring a patient's consent. There is support for my position in proposed section 716, which requires patient consent for electro-convulsive therapy and all surgery, even though such procedures are not necessarily "unusually" hazardous.

The Committee should also establish procedures and guidelines for the performance of experimental research and hazardous procedures and should review and approve each proposal before the research or hazardous procedure may be conducted. This approach was utilized in the Wyatt order ${ }^{199}$ In addition, the court directed the committee, prior to granting approval, to determine that the proposed "research complies with the principles of the Statement on the Use of Human Subjects for Research of the American Association on Mental Deficiency and with the principles for research involving liuman subjects required by the United States Department of Health, Education and Welfare for projects supported by that agency."200 A similar requirement should be imposed by the legislature. ${ }^{200.1}$

\section{Special Treatment Measures for Dangerous Patients}

When a lrospitalized mental patient acts in a manner that threatens serious bodily harm to himself, other patients or staff, or substantial property damage, he nuust be stopped, just as a nonmentally ill person would be prevented from engaging in similar conduct in the cominunity. While there is no time to obtam a court order authoriz-

have been obtained is found in the fact that a similar experiment at the California Institute for Woinen was properly reported to the FDA. See Note, Conditioning and Other Teclinologies, supra note 65 , at 639-40.

199. Wyatt v. Stickney, 344 F. Supp. 373, 380 (M.D. Ala. 1972).

200. Id.

200.1. The Legislative Committee's proposed section 718 was eliminated when the Michigan Legislature passed the Mental Health Code, and a new section 718 was substituted. As enacted, section 718 concerns the administration of chemotherapy-solely. This new legislation is reprinted in note 214.1. Although the chemotherapy provisions are a desirable addition to the Code, the lack of any legislation to govern experimental research projects and hazardous procedures, is, in my opinion, a grievous error. 
ing temporary restraint or seclusion in an emergency situation, statutory safeguards are necessary to prevent misuse or overuse ${ }^{201}$ of these measures to handle supposedly dangerous patients.

The Legislative Committee has proposed two statutes himiting the use of physical restraints ${ }^{202}$ and seclusion. ${ }^{203}$ Proposed section 740

201. See Ferleger, supra note 41 , at $483-93$ (discussion of the "arbitrary and oppressive" use of seclusion and restraints "as currently practiced" in mental hospitals today).

202. Sec. 740. (1) A resident shall not be placed in physical restraint except in the circumstances and under the conditions set forth in this section.

(2) A resident may be restrained only as provided in subsection (3), (4), or (5) and only if restraint is essential in order to prevent the resident froin physically harming himself or others, or in order to prevent him from causing substantial property damage.

(3) A resident may be restrained pursuant to an order by a physician made after personal examination of the resident. An ordered restraint shall continue only for that period of time specified in the order.

(4) A resident may be restrained pursuant to an authorization by a physician. An authorized restraint may continue only until a physician can personally examine the resident.

(5) A resident may be teinporarily restrained without an order or authorization in an emergency. Immediately after imposition of the temporary restraint, a physician shall be contacted. If, after being contacted, the physician does not order or authorize the restraint, the restraint shall be removed.

(6) The governing body of the facility shall establish in writing the maximum length of time ordered, authorized, and temporary restraint may last, the frequency at which a restrained resident shall be examined, the persons qualified to inake the required examinations, the frequency at which opportunities for free movement shall be provided a restrained resident, and other regulations which the governing body deems appropriate.

(7) A restrained resident shail continue to receive food, shall be kept in samitary conditions, shall be given access to toilet facilities, and shall be given the opportunity to sit or lie down.

(8) Restraints shall be relnoved whenever they are no longer essential in order to achieve the objective which justified their application.

(9) Each instance of restraint, full justification for its application, and the results of each periodic examination shall be placed promptly in the record of the resident.

203. Sec. 742. (1) A resident shall not be kept in seclusion except in the circuinstances and under the conditions set forth in this section.

(2) A resident may be placed in seclusion temporarily only pursuant to subsection (5) and only if it is essential in order to prevent the resident from physically harming himself or others, or in order to prevent the resident from causing substantial property damage. A resident may be placed in seclusion upon an authorization or written order only pursuant to subsection (3) or (4) and only if it is essential to prevent the resident from physically harning himself or others, or to prevent the resident from causing substantial property damage, or if seclusion would be of clinical or therapeutic benefit for the resident.

(3) A resident may be placed in seclusion pursuant to an order of a qualified professional person inade after personal examination of the resident. Ordered seclusion shall continue only for that period of time specified in the order.

(4) A resident may be placed in seclusion pursuant to an authorization by a qualified professional person. Authorized seclusion shall continue only until a qualified professional person can personally examine the resident.

(5) Seclusion may be temporarily employed in an emergency without an 
sanctions physical restraint "only if restraint is essential in order to prevent the resident from physically harming himself or others, or in order to prevent him from causing substantial property damage"204 and limits the situations in which this standard may be met. Assuning the criterion is established, restraint may be (1) ordered by a physician only after he has personally examined the patient, ${ }^{205}$ (2) authorized by a physician only until he has time to personally examine the patient, ${ }^{208}$ or (3) temporarily imposed in an emergency until a physician can be contacted. ${ }^{207}$ Proposed section 742 allows seclusion under virtually identical circumstances ${ }^{208}$ but provides an additional ground for a qualified professional person to order or authorize non-

authorization or an order. Immediately after placing the resident in temporary seciusion, a qualified professional person shall be contacted. If, after being contacted, the qualified professional person does not authorize or order the seciusion, the resideut shall be removed from seclusion.

(6) The governing body of the facility shall establish in writing the qualifications necessary to be considered a qualified professional person for purposes of this section, the maximum length of time ordered, authorized, and temporary seclusion may last, the frequency at which a secluded resident shall be examined, the persons qualified to make the required examinations, and other regulations which the govering body deems appropriate.

(7) A secluded resident shall continue to receive food, shall remain clothed unless his actions make it impractical or inadvisable, shall be kept in sanitary conditions, and shall be provided a bed or similar piece of furniture unless his actions make it impractical or inadvisable.

(8) A secluded resident shall be released from seclusion whenever the circuinstance which justified its use ceases to exist.

(9) Each instance of seclusion, full justification for its use, and the results of each periodic examination shall be placed in the record of the resident.

204. Proposed section 740(2). As currently worded, a determination of "essentiality" is required when the issue is whether the patient will physically harm himself or others, but arguably is not required when the issue is whether lie will cause substantial property damage. The proposal should be revised to clarify that a determination of essentiality is required in the latter context as well.

205. Proposed section 740(3), supra note 202.

206. Proposed section $740(4)$, supra note 202. In my opinion, proposed section $740(4)$ is unnecessary and potentially abusive and should be eliminated. Proposed section $740(5)$ permits physical restraints to be employed temporarily in an emergeucy without a physician's personal examination but requires a physician to be contacted iminediately after the patient is restrained. All that is being permitted by section 740 (4) is continued "temporary" restraint on the "authorization" of the physician until he has an opportunity to personally examine the patient. That purpose can be accommodated by additional lauguage in section $740(5)$. To have section $740(4)$ as a separate provision may sanction the use of physical restraints in a nonemergency situation upon the "authorization" of a physician who has not made a personal examination of the patient. Also, the provision does not even require the physician to make an immediate personal examination of the patient after the patient has been placed in physical restraint.

207. Proposed section 740(5), supra note 202.

208. Thus, the deficiencies of the "restraint" proposal, section 740(2) and 740(4), discussed in notes 204 and 206 supra, are equally applicable to the "seclusion" proposal, sections $742(2)$ and $742(4)$. 
temporary, non-emergency seclusion-"if seclusion would be of clinical or therapeutic benefit for the resident." ${ }^{209}$

The governing body of each facility would establish regulations regarding the frequency of periodic examinations of restrained and secluded patients and the maximum duration of these conditions. ${ }^{219} \mathrm{Re}$ straints must be removed "whenever they are no longer essential in order to achieve the objective which justified their application."211 A patient "shall be released from seclusion whenever the circumstance which justified its use ceases to exist."212 Instances of restraint or seclusion are required to be placed in the patient's record. ${ }^{213}$

Critique: The widespread use of tranquilizing drugs has reduced the use of and need for physical restraints and seclusion. Legislative guidance, however, is also needed to prevent potential inisuse or overuse of those chemical restraints. Proposed section 740 is limited in scope to physical restraints. The Legislative Committee has not dealt specifically with chemical restraints, although a more general provision, proposed section $722(1)^{214}$ declares that a mental patient "shall not be physically, sexually, or otherwise abused." Perhaps it can be asserted that orders of excessive medication fall within the prohibition of this statute. However, the Legislative Committee deemed it appropriate to develop specific provisions limiting physical restraint, even though section 722(1) prohibits any form of abuse. Similar particularization is needed for chemical restraints. ${ }^{214.1}$

209. Proposed section 742(2), supra note 203.

210. Proposed section 740(6), supra note 202; proposed section $742(6)$, supra note 203.

211. Proposed section $740(8)$, supra note 202.

212. Proposed section 742(8), supra note 203.

213. Proposed section 740(9), supra note 202; proposed section 742(9), supra note 203. For instances of restraint, there is an additional requirement that recordation be done "promptly." Similar speed should be required when recording instances of seclusion.

214. See note 176 , supra.

214.1. The Michigan Legislature passed the following legislation limiting the use of chemotherapy:

Sec. 718. (1) Chemotherapy shall not be administered to an individual who has been hospitalized by medical certification or by petition pursuant to chapter 4 or 5 until after the preliminary court hearing has been held unless the individual consents to such chemotherapy or unless the administration of such chemotherapy is necessary to prevent physical injury to the individual or others.

(2) Chemotherapy shall not be administered to an individual who has been hospitalized by medical certification or by petition pursuant to chapter 4 or 5 on the day preceding and on the day of his full court hearing unless the individual consents to such chemotherapy or unless the administration of such chemotherapy is necessary to prevent physical injury to the individual or others. No. 258, [1974] Mich. Pub. Acts. This legislation was catalyzed by the case of Bell v. Wayne County Gen. Hosp., No. 36384 (E.D. Mich., June 3, 1974). The provisions prohibit any use of drugs at the statutorily prescribed times. However, they do not elimi- 
In Wyatt, the court declared that patients have a "right to be free from unnecessary or excessive medication."215 The court issued a number of requirements governing issuance of drugs, responsibility for administration, dosage limitations, recording, review, and termination of orders. ${ }^{216}$ A Mental Treatment Standards Committee, if established, would be the appropriate body to formulate guidelines, similar to those ordered in Wyatt, for the use of drugs on dangerous patients and, in fact, on all patients.

Proposed sections $740(6)$ and $742(6)$ authorize the superintendent of each mental hospital to establish crucial regulations governing duration and review of restraint and seclusion. Regulations of such importance should be specifically included in the legislation itself and uniformly applied throughout the state. For example, a Massachusetts statute requires any use of restraint to be reviewed at least every eight hours by the superintendent or designated physician. ${ }^{217}$ In $W y$ $a t t$, the court specifically limited the emergency use of restraints or isolation to one hour's duration. Additionally, the court required an appropriate written order by a "Qualified Mental Health Professional"213 if restraint or isolation is to be contimued thereafter. Any such order is effective for no more than 24 hours and must be renewed if re. straint or isolation is to be contimued. Qualified ward personnel must see the restrained or isolated patient and chart his physical and psychi-

nate the use of drugs at other times or limit the dosages permitted when drugs are used. Thus, the legislation does not adequately prevent misuse and overuse of chemical restraints.

215. Wyatt v. Stickney, 344 F. Supp 373, 380 (M.D. Ala. 1972).

216. The court in Wyatt wrote:

No medication shall be administered unless at the written order of a physician. The superintendent of the hospital and the attending physician shall be responsible for all medication given or administered to a patient. The use of medication shall not exceed standards of use that are advocated by the United States Food and Drug Administration. Notation of each individual's medication shall be kept in his medical records. At least weekly the attending physician shall review the drug reginen of each patient under his care. All prescriptions shall be written with a termination date, which shall not exceed 30 days. Medication shall not be used as punishnent, for the convenience of staff, as a substitute for program, or in quanitites that interfere with Id. the patient's treatment program.

217. Mass. Gen. Laws ch. 123, § 21 (Supp. 1973).

218. "Qualified Mental Health Professional" is defined as:

(1) a psychiatrist with three years of residency training in psychiatry;

(2) a psychologist with a doctoral degree fron an accredited program;

(3) a social worker with a master's degree from an accredited program and two years of clinical experience under the supervision of a Qualified Mental Health Professional;

(4) a registered nurse with a graduate degree in psychiatric nursing and two years of clinical experience under the supervision of a Qualified Mental Health professional.

Wyatt v. Stickney, 344 F. Supp. 373, 379 (M.D. Ala. 1972). 
atric condition every hour..$^{210}$ If the legislature is not disposed to adopt similar specific constraints on the use of physical restraint and seclusion, then it should authorize an independent agency, such as the Mental Treatment Standards Committee, to do so.

Proposed sections 742(3) and 742(4) permit a "qualified professional person" to order and authorize seclusion. This is a questionable departure froin the provisions dealing with physical restraints. Physical restraint is permitted only to prevent harm to person or property. There is no suggestion in proposed section 740(2) that restraint is or may be "therapeutic" to the patient. Nevertheless, only a physician may order or authorize physical restraint. Seclusion, on the other hand, is permitted by proposed section 742(2) not only to prevent harm to person or property but also if it "would be therapeutic or of similar benefit for the resident." If some seclusion is indeed therapeutic or beneficial, only a physician should be able to order or authorize its use for that purpose.

Although temporary or short-term seclusion may be deemed therapeutic, solitary confinement for any substantial length of time is not therapy. In Wyatt, the court issued identical regulations governing duration of physical restraint and isolation. Though the legislature need not treat them as coequals, it should establisl by statute, or authorize the Mental Treatment Standards Committee to establish, a short maximum period of time that seclusion may be contimued.

Restraint or temporary seclusion is authorized in proposed sections 740(2) and 742(2) only if it "is essential" 220 in order to prevent the resident from inflicting physical harm upon himself or others, or causing substantial property damage. There is no statutory direction on how to determine essentiality. For example, is a recent overt act of violence an imdisputable prerequisite to a finding of essentiality, or is an attempt or threat sufficient? Is escape subsuned under the rubric "harm to others"? May a patient who merely presents an escape risk be physically restrained or temporarily secluded if he will harm only someone who attempts to block his escape?

219. For nonemergency situations, the Wyatt court authorized physical restraint or isolation only on the written order of a Qualified Mental Health Professional, which may be entered only after the Professional has personally seen the patient and evaluated the situation. Wyatt v. Stickney, 344 F. Supp. 373, 380 (M.D. Ala. 1972). Presumably a personal examination by the Professional is also required for him to enter "an appropriate order in writing" in an emergency situation where restraint or isolation is being used prior to his being consulted.

220. To the extent that physical restraints or seclusion are ordered as alternatives to each other in similar situations, there may be a logical inconsistency in declaring statutorily that each cannot be ordered unless it is essential to do so. If temporary seclusion is appropriate to a situation, it should be viewed as "essential" and therefore permissible, even though physical restraints could have been viewed as equally "essential." 
Besides suggesting that the concept of essentiality be further defined, I also suggest that the conditions justifying restraint or seclusion be further circumscribed to protect the already limited freedom of the patient. A Legislative Committee proposal defines a dangerous mentally ill person as one "who as a result of that mental illness can reasonably be expected within the near future to intentionally or unintentionally seriously physically mjure himself or another person, and who has engaged in an act or acts or made significant threats that are substantially supportive of the expectation." 221 Only if that standard of dangerousness is established can the individual be deprived of his liberty and involuntarily confined in an institution. ${ }^{22}$ If the confined individual is not to lose any more of his freedom unnecessarily, a similar standard should be satisfied before the extraordinary nieasures of restraint or seclusion can be imposed on him. As a minimum, I would require that the patient, while a resident in the institution, have inade significant threats of, or inflicted serious physical harm to, himself or others before the extraordinary neasures of a restraint or seclusion can be imposed on him.

Since, under the proposed commitment provision, causing substantial propenty damage does not warrant initial involuntary confinement it is questionable that such conduct, or threats of such conduct, in the institution should warrant restraint or seclusion of the confined inental patient. Drawing a distinction between harm to persons and harm only to property would underscore the legislative policy that restraint and seclusion are permitted only in exceptional circumstances. Note that a property-destructive patient may place institutional employees in a situation of personal danger. However, their decision to use restraints or seclusion should be based on the "personal harm" not "property harm" criterion.

The principle of "the least restrictive alternative," discussed previously, ${ }^{223}$ requires a search for less constraining substitutes to institutionalization of the inentally ill. This principle has been accepted in developing case law $^{224}$ and embodied in the proposals of the Legisla-

221. Proposed section 401(a).

222. There is an alternative commitment criterion proposed for nondangerous but "helpless" mentally ill persons:

A person who is mentally ill, and who as a result of mental illness is unable to attend to those of his basic physical needs such as food, clothing, or shelter that must be attended to in order for him to avoid serious harm in the near future, and who has demonstrated that inability by failing to attend to those basic physical needs. Proposed section 401(b).

223. See discussion in text accompanying notes 22-28 supra.

224. In Lake v. Cameron, 364 F.2d 657 (D.C. Cir. 1966), the Court of Appeals for the District of Columbia Circuit held that prior to ordering the involuntary confinement of an individual in a mental hospital, the committing court must explore 
tive Committee. ${ }^{225}$ Moreover, there appears to be no legitimate basis for depriving confined mental patients of the right to the "least restrictive" conditions of confinement within the institutions. ${ }^{226}$ At least as to the physical conditions of confimement, this principle has also been accepted in developing case law. ${ }^{227}$ It is embodied in the following proposal of the Legislative Committee:

Sec. 744. The freedom of movement of a resident shall not be restricted more than is necessary to provide mental health services to him, to prevent injury to him or to others, or to prevent substantial property damage. . . .228

Obviously, no restraint at all is the preferred restraint. However, assuming that the criteria for the imposition of restraint are met, proposed seation 744 adequately limits permissible restraint to the least restrictive necessary to achieve the legitimate goal.

The inore difficult problem, however, concerns the patient whose propensity to commit dangerous and destructive acts cannot be adequately controlled by temporary use of tranquilizers, restraint, or seclusion. In some situations, a patient's alleged "dangerous" behavior may necessitate substantial restriction of his rights as a patient and denial of treatment opportunities generally afforded to other patients. The Mental Treatment Standards Committee should be authorized to establish what constitutes a substantial restriction on treatment opportunities. For example, placing a patient in a locked ward would probably not be a substantial restriotion on a patient's treatment opportunities. On the other hand, transferring a patient to a locked ward for an indefinite length of time and curtailing his movement to various therapies available in other parts of the imstitution inight constitute such a restriction.

Maximum security confinement, whether in a separate ward of

alternatives to this deprivation of liberty and satisfy itself that no less onerous disposition, such as outpatient treatment with a guardian appointed, would serve the purpose of the commitment. See also Lessard v. Schmidt, 349 F. Supp. 1078, 1095-97 (E.D. Wis. 1972), vacated and remanded for specificity in the order, 94 S. Ct. 713 (1974); Dixon v. Attorney General, 325 F. Supp. 966, 974 (M.D. Pa. 1971).

225. Proposed section $469(1)$ provides:

Prior to ordering any course of treatment, the court shall determine whether there exists an available program of treatment for the individual which is an alternative to hospitalization. The court shall not order hospitalization without a thorough consideration of available alternatives.

226. See discussion in text accompanying notes 30-32 supra.

227. See, e.g., Covmgton v. Harris, 419 F.2d 617 (D.C. Cir. 1969), and discussion in text accompanying notes 30-31 supra. See also Wyatt v. Stickney, 344 F. Supp. 373, 379 (M.D. Ala. 1972), and discussion in note 32 supra.

228. ". . . except that security precautions appropriate to the condition and circumstances of a resident admitted by order of a criminal court or transferred as a sentence serving convict from a penal institution may be taken." Proposed section 744. 
the same institution or in a different, more secure institution, constitutes an extreme and perhaps paradigm instance of restricting a patient's rights and treatment opportunities. The Michigan Department of Mental Health has admitted that "an effective psychiatric treatment program is not compatible with a maximum security environment." ${ }^{229}$ And unlike restramt or seclusion, the removal of the individual from the general patient population into maximum security confinement is rarely a temporary dislodgment.

In Covington v. Harris, ${ }^{230}$ the court held that a mental patient may challenge his administrative placement into the maximum security ward. Although a mere request for a change of hospital dormitories or for a transfer between substantially similar wards will not sustain a petition for habeas corpus, the writ can be invoked to obtain a transfer to a less restrictive ward withm the same hospital. The court noted that maximum security facilities for the mentally ill

have, in the past, notoriously rivalled maximum security prisons in the pervasiveness of their restraint upon liberty and the totality of their impositions upon dignity. . . . Thus, there is reason to beheve that confinement in John Howard [the maximum security ward] is not normally contemplated for civilly committed patients and entails extraordinary deprivations of liberty and dignity which inake it, in effect, more penitentiary than mental hospital, even if it also provides some treatment. ${ }^{231}$

Subsequent decisions in the same jurisdiction have specified minimal protective procedures which would extend due process to maximum security transfers. ${ }^{232}$

In 1972, New York enacted legislation ${ }^{233}$ that is even inore protective of the mental patient's right not to be transferred into maximum security confinement in a new institution. ${ }^{234} \mathrm{~A}$ patient can be trans-

229. Department of Mental Health, Prelimanary Prospectus for Special Security Hospital AND Forensic Center 9 (1968). See Morris, Mental Illness and Criminal Commitment in Michigan, 5 U. MICH. J. LAW REFORM 1, 11-14 (1971) (discussion of the differences in treatment of patients in the "regular" state mental hospitals and Ionia State Hospital, Michigan's maximum security institution). See also Morris, The Confusion of Confinement Syndrome: An Analysis of the Confinement of Mentally Ill Criminals and Ex-Criminals by the Department of Correction of the State of New York, 17 BuFF. L. REv. 651, 654-59 (1968) (discussion of the differences in treatment of patients in the "regular" mental hospitals and Matteawan State Hospital, New York's maximum security institution); Wexler \& Scoville, supra note 56, at 235-36 (excerpts from the Annual Report of the Arizona State Hospital describing conditions in the Maximum Security Unit).

230. 419 F.2d 617 (D.C. Cir. 1969).

231. Id. at 622-23.

232. Jones v. Robinson, 440 F.2d 249 (D.C. Cir. 1971); Williams v. Robinson, 432 F.2d 637 (D.C. Cir. 1970).

233. N.Y. Sess. Laws 1972, ch. 251, § 29.13.

234. In Kesselbrenner v. Anonymous, 33 N.Y.2d 161, 305 N.E.2d 903, 350 
ferred only if he is a "dangerous" patient, defined by the statute as one who

has committed or is liable to commit an act or acts which, if committed by a person criminally responsible for his conduct, would constitute homicide or felonious assault or is so dangerously mentally disabled that his presence in the department hospital or school is dangerous to the safety of other patients therein, to the officers or employees thereof, or to the community. ${ }^{235}$

Prior to transfer, the allegedly dangerous patient is entitled to notice and a court hearing at which he is represented by counsel. ${ }^{230}$ If the patient is determined to be dangerous, transfer can be ordered only for a period not to exceed six months. Subsequent orders authorizing retention in maximum security for similar six-month periods require a new court hearing and a determination that the patient continues to meet the statutory criteria of dangerousness.

Because a maximum security ward is functionally distinct from other wards, and because placement there decreases treatunent potential and increases restraints on personal liberty, the patient should be protected against unwarranted transfers. Judicial intervention is necessary to scrutinize the propriety of any proposed transfer to maximum security. Thus, a statutory standard and procedures similar to the New York legislation described above should be enacted. ${ }^{237}$

\section{Specific Provisions Involving Aspects of Privacy and Autonomy}

"Patients have a right to privacy and dignity"238 was the first standard articulated in the order in Wyatt establishing minimum constitutional standards for adequate treatunent. Arguably, proposed section 702(a), which declares that a mental patient is not deprived "of his rights, benefits, or privileges," and section 704(3), which states

N.Y.S.2d 889 (1973), the statute was held to violate the patient's constitutional right to due process. Notwithstanding the procedural protections provided by the statute, a finding that the civilly committed mental patient was "dangerous" resulted in his transfer from a facility administered by the Department of Mental Hygiene to Matteawan State Hospital, administered by the Department of Correction. Beeause the patient was not charged with nor convicted of a crime, such a result was "constitutionally invidious."

235. N.Y. Sess. Laws 1972, ch. 251 , § 29.13 (a).

236. Pending the hearing, however, the court was also empowered to "forthwith order" the transfer of the paticnt if the transferring hospital was not able to properly care for the patient and the "patient was in need of immediate treatment." N.Y. Sess. Laws 1972, ch. 251, § 29.13(h).

237. See Morris, Mental Illness and Criminal Commitment in Michigan, supra note 229, at 58-60, for a specific legislative proposal to accounplish the desired result. The desirability of this approach is not affected by Kesselbrenner v. Anonymous, 33 N.Y.2d 161, 305 N.E.2d 903, 350 N.Y.S.2d 889 (1973), discussed in note 234 supra.

238. Wyatt v. Stickney, 344 F. Supp. 373, 379 (M.D. Ala. 1972). 
that "[t]he provisions of this chapter shall be construed to protect and promote the basic human dignity to which a recipient of services is entitled," include a right to privacy and maximum patient autonomy. Nevertheless, these general statutory provisions are supplemented by specific legislative proposals which deal with the four problems areas discussed below. Such details are desirable here and in other areas where generalities do not provide sufficiently definitive answers to common conflicts arising in the institutional setting. ${ }^{239}$ Curtailing abuses in the exercise of discretion requires a precise statement of the authority and limits of authority of institutional personnel in various situations. This would permit conduct to be evaluated objectively. Thus, for example, a statute should indicate circumstances that warrant and conditions that govern searohes for contraband.

The adoption of policies by the Department of Mental Health to implement the general statutory provisions may resolve many daily problems of institutional life. For example, departmental regulations may delineate the hospital's obligation to provide adequate clothing for patients who do not have suitable clothing of their own, laundering services for all patient clothing and linen, regular physical exercise for patients, and religious services for patients who desire to attend them. ${ }^{240}$

\section{a. Fingerprinting and photographing of patients}

In many states, all mental patients are routinely fingerprinted and, in soine instances, photographed upon admission to the state hospital. Hospital administrators justify these procedures "as needed devices to aid in identification of patients, identification of former patients at State mental hospitals, and the possible discovery of prior criminal convictions (which might be necessary to uncover or aid in proper diagnosis and treatment)." ${ }^{241}$ In Winters v. Miller, ${ }^{242}$ the court accepted these justifications, saying that fingerprinting no longer carries with it a stigma of criminality. ${ }^{243}$ In the absence of "some specific illustra-

239. One might be concerned that expressly delineating various rights in statutes may impliedly limit or eliminate other unspecified rights. Proposed section 704(2) would alleviate that problem: "The rights enumerated in this chapter shall not be construed to replace or limit any other rights, benefits, or privileges of a recipient of services."

240. Each of these "rights" was considered a minimum constitutional standard for adequate treatment in Wyatt v. Stickney, 344 F. Supp. 373, 380-81 (M.D. Ala. 1972).

241. Winters v. Miller, 446 F.2d 65, 71 (2d Cir. 1971).

242. 446 F.2d 65 (2d Cir. 1971), cert. denied, 404 U.S. 985 (1971).

243. For precedent, the court relied on Thom v. New York Stock Exchange, 306 F. Supp. 1002 (S.D.N.Y. 1969), affd per curiam sub nom., Miller v. New York Stock Exchange, 425 F.2d 1074 (2d Cir. 1970), cert. denied, 398 U.S. 905 (1970). There a 
tions" of stigma, the court would not assume that it attaches when patients in mental hospitals are routinely fingerprinted.

The degislature need not require the same degree of proof demanded by the court in Winters. Even if there is only a possibility that a stigma of criminality or other anti-therapeutic consequence may attach, the advantages of routinely fingerprinting and photographing all patients do not justify taking such a risk.

In most instances, a patient's name can be ascertamed from the patient himself, from documents in his possession, or from the relative or other person who petitioned for commitınent. Only if an individual patient cannot be identified by other means should fingerprinting or photographing be permitted. If fingerprints or photographs are required, they should be kept confidential and returned to the patient or destroyed when no longer needed for their original purpose or when the patient is released from the institution. The Legislative Committee has proposed statutes ${ }^{244}$ in accordance with these principles.

constitutional challenge to a statute which required the fingerprinting of employees of member firms of all national security exchanges was rejected. The Winters court was unwilling to aecept the appellant's bare assertion that the cases were distinguishable on their fact situations alone.

244. Sec. 724. (1) A recipient of mental health services shall not be fingerprinted or photographed by the provider of those services except in the eircumstances and under the conditions set forth im this section. As used in this section, photography includes the use of still, motion picture, and videotape cameras.

(2) Fingerprints or photographs may be taken and used in order to provide services to a recipient or in order to determine the name of the recipient.

(3) Fingerprints or photographs taken in order to provide services to a recipient, and any copies thereof, shall be kept as part of the record of the recipient.

(4) Fingerprints or photographs taken in order to determine the name of a recipient shall be kept as part of the record of the recipient, except that when necessary the fingerprints or photographs may be delivered to others for assistance in determining the name of the recipient. Fingerprints or photographs so delivered shall be returned together with any copies which have beeu made. Those receiving fingerprints or photographs shall be informed of the requirement that return be made. Upon return, the fingerprints or photographs, together with any copies, shall be kept as part of the record of the recipient.

(5) Fingerprints or photographs in the record of a reeipient, and any copies thereof, shall be given to the recipient or destroyed when they are no longer essential in order to achieve one of the objectives set forth in subsection (2), or upon discharge of the recipient, whichever occurs first.

(6) Photographs may be taken and used for educational, informational, training, or purely personal or social purposes. A photograph of a reeipient shall in no event be taken or used pursuant to this subsection if the recipient has indicated his objection.

To better insnre the return of fingerprints and photographs, an additional sentence should be added to proposed section 724(4): "No fingerprints or photographs shall be delivered to others unless assurance is given that the fingerprints or photographs, together with any copies, will be returned." 


\section{b. Communication and visitation}

The right of mental patients to communicate with some members of the outside world through correspondence, telephone, and visitation has been recognized by more state statutes than any other "patients' right."245 The legislative response is based on the belief that communication may expose instances of wrongful hospitalization. Also, the courts have held in a number of cases that a hospital's failure to forward a mental patien's letters to his attorney constitutes an unreasonable restraint on the patient's right to a writ of habeas corpus. ${ }^{246}$ As a result, unlimited and uncensored correspondence with judges, attorneys, and public officials is often provided for by statute, and visitation by those persons is generally assured. ${ }^{247}$

Today, there are reasons for extending the rights of communication and visitation. The overwhelming number of mental patients are not institutionalized for extended periods of time, ${ }^{248}$ so there is a need to keep patients in contact with the "real world" to which they will be returning in a matter of a few months. Communication and visitation help eliminate isolation and depersonalization within the institutions. Contact with outside persons may be an integral part of modern treatment efforts to restore patients to a level of social functioning that will permit release from the institution. ${ }^{249}$

Although unrestricted communication with judges and attorneys is desirable and even necessary, the right to communicate and visit with others may be properly qualified in some instances. General censorship of all incoming or outgoing mail and telephone calls is not warranted, but a proposal establishing and encouraging a broad right to communication must also deal specifically with the unusual circun1stances where restrictions would be justified.

The Legislative Committee has proposed:

Sec. 726. (1) A resident is entitled to unimpeded, private, and uncensored communication with others by mail and telephone and to visit ${ }^{250}$ with persons of his choice, except in the circumstances and under the conditions set forth in this section.

245. See 1971 BAR REPORT, supra note 5, at 174-79.

246. See, e.g., Hoff v. State, 279 N.Y. 490,18 N.E.2d 671 (1939); People ex rel. Jacobs v. Worthing, 167 Misc. 702, 4 N.Y.S.2d 630 (Sup. Ct. 1938).

247. See 1971 BAR REPORT, supra note 5, at 174-79.

248. See generally the discussion in text accompanying notes 47-50 supra and the sources cited in those notes.

249. See the discussion in text accompanying notes 51-61 supra.

250. Proposed section $726(1)$ should be rephrased to indicate the drafter's intention that visitation as well as communication shall be "unimpeded, private, and uneensored." To achieve this clarification, it may be sufficient to substitute the word "visitation" for the words "to visit" as they appear in proposed section 726(1). 
(2) Each facility shall endeavor to implement the rights guaranteed by subsection (1) by making telephones reasonably accessible, by ensuring that correspondence can be conveniently received and mailed, and by making space for visits available. Writing materials and postage shall be provided in reasonable amounts to residents who are unable to procure such items.

(3) Reasonable times and places for the use of telephones and for visits may be established and, if established, they shall be in writing. ${ }^{251}$

(4) The right of a resident to communicate by nail or telephone may be limited if each limitation is essential in order to prevent the resident from violating a law or to prevent substantial and serious physical or mental harm to the resident, and if each limitation is approved by the head of the facility or his designee.

(5) A resident may be prevented by a facility from telephoning an individual who has complained to the facility of previous telephone harassment by the resident and has requested that the resident be prevented from calling him in the future.

(6) The right of a resident to visit with persons of his choice may be limited if each limitation is essential in order to prevent substantial and serious physical or mental harm to the resident, and if each limitation is approved by the head of the facility or his designee.

(7) No limitation upon the rights guaranteed by subsection (1) may apply between a resident and an attorney or a court, or between a resident and other persons when the communication involves matters which are or may be the subject of legal inquiry.

(8) Any limitation adopted under the authority of subsection (4), (5) or (6), the date it shall expire, and justification for its adoption shall be promptly noted in the record of the resident.

Critique: The criteria propounded in sections $726(4)$ and (6) for limiting a patient's general rights to communication or visitation appear to be sufficiently circumscribed. In many respects, these stand. ards are more protective of the rights ${ }^{252}$ than those contained in the or-

251. It is insufficient that the hospital rules for communication and visitation "shall be in writing." The statute should also require that patients be notified of these rules. See note 142 supra (discussion of measures which hospitals should be required to undertake to notify patients of their rights). Similar efforts should also be mandated for notification of hospital rules.

252. However, the proposed language does not clearly indicate whether a nonpatient has an unlimited right to conmmunicate with a patient. Arguably, proposed section $726(4)$ only permits limitations to be imposed on a patient's attempt to communicate with others. It does not necessarily protect the patient's right to have others attempt to communicate with him. Such protection should be specifically afforded by statute. The general language of proposed section $726(1)$ may be insufficiant to accomplish the desired result. 
der in the Wyatt case. In Wyatt, the court authorized the individual in charge of the patient's treatment plan to impose restrictions on the patient's right to visitation, telephone communication, and receipt of mail but did not subject the exercise of his discretion to any qualifications. ${ }^{263}$

The proposed statutory protection, however, nuay be illusory. For example, how is the determination made that it is "essential" to impose restrictions? The proposed statutes only state the patient's rights to communication and visitation. They provide no guidance to those who must determine whether the statutory requirement of essentiality has been established so that a right may be limited. The statutes also fail to identify those individuals who have the authority to limit these rights. The drafters apparently contemplated that a medical decision be made since communication and visitation rights nuay be limited primarily upon a determination that it is "essential" to do so in order "to prevent substantial and serious physical or nental harn to the resident ...." Although a decision to limit these rights must be approved by the head of the facility, the statute should require that the determination itself be made by the physician in clarge of the patient's treatment plan. The proposed statute requires that the "justification" for adopting a restriction be noted in the patient's record; it should also require that the physician, prior to ordering any restriction, make a personal examination of the patient and specify the circunistances which justify his decision.

It inay be unrealistic to require, as in proposed section $726(8)$, that the expiration date for a limitation be "promptly noted" in the patient's record. In many instances, the person ordering the limitation will not know how long the conditions justifying the restrictions will continue. It would be preferable for the statute to require that the order of limitation expire after a specified short period of time, perhaps seven days. Additionally, the statute should provide that a new order may be issued when the first expires, if it is determined that conditions still warrant the restriction. The patient's ability to contest the validity of an order limiting his communication and visitation rights should also be insured. ${ }^{254}$

\section{c. Control of personal property}

Proposed section 702(b) declares that hospitalization alone "[s]hall not cause the person to be deemed legally incompetent." This reflects the legislative trend toward complete separation of the two is-

253. Wyatt v. Stickney, 344 F. Supp. 373, 379-80 (M.D. Ala. 1972). However, the Wyatt order establishes an unrestricted right of patients to send sealed mail.

254. See Part IV C of this Article infra. 
sues. ${ }^{255}$ The recognition of a general right of mental patients to control their personal property while in the hospital would, therefore, be in keeping with the legislative purpose. However, many hospitals exercise some control over all patients' property, regardless of whether individual patients have been adjudicated incompetent or not. ${ }^{250}$ When there are legitimate reasons to subordinate the patient's "property control" right to the hospital's authority, they should be articulated by statute.

Money presents a unique problem, since it has value only if the patient has the ability to spend it. Institutional safekeeping of all money, with a proper accounting, should be permitted, provided patients retain the right to make unlimited expenditures.

The Legislative Committee has proposed:

Sec. 728. (1) A resident is entitled to receive, possess, and use all personal property, including clothing, except in the circumstances and under the conditions set forth in this section.

(2) Each facility shall provide a reasonable amount of storage space to each resident for his clothing and other personal property.

(3) The governing body of a facility may exclude particular kinds of personal property from the facility. Any exclusions shall be officially adopted and shall be in writing.

(4) The person in charge of the plan of services for a resident may limit the rights guaranteed by subsection (1) if each limitation is essential: erty.

(a) In order to prevent theft, loss, or destruction of the prop-

(b) In order to prevent the resident from physically harming himself or others.

(c) In order to achieve a compelling treatinent objective.

(d) In order to assure the effective functioning of the facility.

(5) Any limitation adopted under the authority of subsection (4), the date it shall expire, and justification for its adoption shall be promptly noted in the record of the resident. ${ }^{257}$

(6) Any limitation adopted under the authority of subsection (4) shall be removed when the circumstance which justified its adop-

255. 1971 BAR REPORT, supra note 5, at 254, 273-79.

256. See the discussion in text accompanying notes 118-20 supra.

257. The difficulties in "promptly" noting the expiration date for a limitation of a patient's right has been discussed previously in the text immediately preceding note 254 supra. The snggestions offered in that discussion-a definite expiration date for the limitation after a short period of time, the issuance of a new order if warranted by conditions existing at the time the first order expires, and the ability of the patient to contest the validity of an order of limitation-are repeated here in the context of limitations which may be imposed on a patient's right to control his property. 
tion ceases to exist. ${ }^{258}$

(7) A receipt shall be given to a resident for any of his personal property taken into the possession of the facility. Any personal property in the possession of a facility at the time the resident to whoin the property belongs is released from the facility shall be returned to the resident.

Proposed section 730 specifies that a state mental hospital may require a patient to turn over his money ${ }^{259}$ to the institution for safekeeping. The money is to be accounted for in the patient's name, ${ }^{260}$ and the patient is entitled to easy access to the money and may spend it as he chooses. ${ }^{261}$ Subsection (4) provides for exceptions:

A department facility may deny a resident the access to and ability to spend or otherwise use the money in his account only when a determination has been made that the denial is essential in order to prevent the resident from unreasonably and significantly dissipating his assets. In each facility there shall be one person designated in writing to make such determinations. The policies and procedures governing such determinations, including the evidence necessary to support a denial of the resident's rights, shall be set forth in writing by the department. When denial is made, the resident shall continue to be allowed to spend or otherwise use the money in ways which would not constitute significant and unreasonable dissipation of the assets. ${ }^{262}$

258. Proposed section 728(6) should be reworded to clarify that the limitation should be removed if the circumstance which justified its adoption ceases to exist, even though the expiration date noted in the patient's record has not been reached.

259. Proposed section 730(1) provides: "For purposes of this section, 'money' includes any legal tender, note, draft, certificate of deposit, stock, bond, check, or credit card."

260. Proposed section $730(2)$ provides:

A department facility may require that all noney which is on the person of a resident, which comes to a resident, or which the facility receives in place of the resident under a benefit arrangenent or otherwise be turned over to the facility for safekeeping. The inoney shall be accounted for in the name of the resident. Upon request, money accounted for in the name of a resident shall be turned over to a legal guardian of the resident.

261. Proposed section $730(3)$ provides:

(3) A resident of a department facility is entitled to easy access to the inoney in his account and to spend or otherwise use the money as he chooses, except as provided in subsection (4). Policies and procedures shall be established in writing for each facility which create procedures giving residents easy access to the money in their account and which enable the money to be spent or otherwise used as the resident chooses.

262. Other proposals dealing with the control of patients' money and other funds are:

Sec. 730. (5) Money accounted for in the name of a resident of a department facility may be deposited with a financial institution. Any earnings attributable to money in an account of a resident shall be credited to that account.

(6) All money, mcluding any earnings, in an account of a resident of a department facility shall be delivered to the resident upon his release from the facility. 
Critique: Proposed section 728(3) offers no guidance to a facility in determining what "kinds" of personal property may be excluded from the institution. The statute should indicate the justifications for excluding categories of property. For example, propenty, like weapons or narcotics, which would present a potential and serious danger to the health or safety of patients and treating personnel, and property of significant value, such as jewelry, which is especially susceptible to loss or theft, could be excludable categories. Each facility should be required by statute to list the specific items within each statutory category that it excluded and to notify patients of these exclusions at time of admission. ${ }^{263}$

The authority granted to a state mental hospital ${ }^{204}$ by proposed seotion 730(4), whicl would deny a patient botll access to and the ability to spend his own money, is of questionable constitutional validity and of doubtful desirability. In essence, the proposal permits an administrative adjudication of legal imcompetence. The admimistrative determination that it is "essential" to deny a patient his money in order to prevent him "from unreasonably and significantly dissipating his assets" is not likely to be viewed as unbiased in light of the institution's right to reimbursement for services rendered in the past and to be rendered in the future. ${ }^{265}$ At most, a statute should authorize the hospital

(7) The department shall establish policies and procedures designed to ensure that money in the accounts of residents is safegnarded against theft, loss, or misappropriation.

Sec. 732. A department facility may accept funds which a parent, guard. ian, or other person wishes to provide for the use or benefit of a resident of the facility. The possession and use of funds so provided shall be governed by section 730 and by any additional directions given by the provider of the funds.

Sec. 734. A department facility may accept an appointment to scrve as a representative payee, fiduciary, or in a similar capacity for payments to a resident under a public or private benefit arrangement. Funds so received shall be subject to section 730 except to the extent laws or regulations governing payment of the benefits provide otherwise.

263. Additionally, a statutory distinction could be drawn between personal belongings, such as clothing or a watch which the patient may be wearing when he is adınitted to the hospital, and other personal property, such as furniture, which has value but is of limited utility in the facility and which may, in addition, require an inordinate amount of space for whatever utility it has.

264. Proposed section 730(4) does not extend its authorization to non-Department of Mental Health facilities. Apparently, a non-Department facility may exclude money as a "kind" of property in accordance with proposed section 728(3). Quaere: May a Department of Mental Health facility exclude all money pursuant to proposed section 728(3)? Proposed section 730, by providing for the safekeeping of patients' funds by Department facilities seems to imply that the exclusion of all money from a Department facility is prohibited. The proposals should be revised to make this implication more explicit.

265. Taking control of a patient's property to defray the costs of hospitalization without a prior adjudication of incompetency of the patient may be a constitutional violation of due processs, The United States Supreine Court has held unconstitutional 
administration to initiate incompetency proceedings when, in its judgment, the statutory criteria for incompetency have been established. Temporary authority to withhold the expenditure of funds, pending a judicial decision on the question of competency, may be allowable.

\section{d. Patient labor}

It has been said that many state mental hospitals would not be able to function if patient labor, for which most hospitals pay nothing, was suddenly withdrawn. ${ }^{266}$ Inadequate staffing and inadequate funding of the mental institutions may necessitate, but cannot justify, institutional "peonage."267 Any patient labor-particularly, but not exclusively, uncompensated institution maintenance labor-may be seen as involuntary servitude in contravention of the thirteenth amendment. There are, however, legitimate therapeutic advantages to some forms of patient labor. Psychiatrists assent that to relieve the monotony of institutional life, "a majority of patients request productive and useful activity as well as a job to perform within a few days after admission."208 The American Bar Foundation has similarly opined:

Therapeutically, no doubt many benefits are derived from occupational activities in the hospital community. These activities, if properly selected and supervised, can become an integral part of the therapy program and an aid in training the patient for his postrelease vocation. 209

The real danger is that, under the guise of therapy, the needs of patients may again be subordinated to the needs of the institution. It cannot be assumed that work therapy, even paid work therapy, is equally beneficial to all patients at all times. Individualization is the key consideration here, just as it is in any institutional treatment program.

If work is a part of the patient's therapeutic program, is payment for his services desirable or warranted? While it may seen ludicrous to pay a patient for therapy he is receiving, remuneration may be justi-

a Wisconsin statute which permitted garnishment of wages before a judgment had been obtained against the debtor. Snaidach v. Family Finance Corp., 395 U.S. 337 (1969). See also Fuentes v. Shevin, 407 U.S. 67 (1972), which held that state replevin laws violated the due process clause of the fourteenth alnendment because they did not provide for a hearing before chattels were taken from their possessor.

266. B. Ennis, The Rights of Mental Patients 60 (1973); Reibman, supra note 183 , at 541 .

267. Adlestein \& Jolly, Rights of Mental Patients to Treatment and Remuneration for Institutional Work-Comments by the Office of Mental Health, 39 PA. BAR Ass'N Q. 548, 550 (1968).

268. Id. at 549 .

269. 1971 BAR REPORT, supra note 5, at 166. Einploying patients in actual productive settings within the hospital may also permit a realistic evaluation of work potential. Adlestein \& Jolly, supra note 267 , at 549. 
fied. Because patients are financially responsible to the state for their care in the institution, it seeins patently unfair to expect them to pay for being permitted to work for nothing.

Paying patients for work performed will not necessarily make that work less therapeutic but, to the contrary, may make it even more beneficial. For example, the thought of coinpensation for their services may dispel the lethargic attitude of some patients. Payment for patient labor is no panacea, but it may have solne desirable results in individual cases.

Paying patients for their labor may also have two undesirable effects. Some patients may wish to prolong their stay at the institution, defeating the therapeutic policy of returning patients to the community as soon as they are ready for return. This danger is minimal, however, because the institution physician, not the patient, determines when the patient is ready for release. There is a corresponding concern that if an institution pays a patient for his work, this fact might be viewed as justification for retaining an especially valuable worker beyond the time when he could return to the community. Rather than eliminating patient pay, a statutory procedure can and should be established to protect a patient who feels that the institution is taking undue advantage of his talents. ${ }^{270}$

\section{The Legislative Committee has proposed:}

Sec. 736. (1) A resident may perform labor which contributes to the operation and maintenance of the facility for which the facility would otherwise employ someone only if the resident voluntarily agrees to perform the labor, engaging in the labor would not be inconsistent with the plan of services for the resident, and the amount of time or effort necessary to perform the labor would not be excessive. In no event shall discharge ${ }^{271}$ or privileges be conditioned upon the performance of such labor.

(2) A resident who performs labor which contributes to the operation and maintenance of the facility for which the facility would

270. See Part IV C of this Article infra.

271. Although proposed section $736(1)$ proclaims that "discharge" is not to be conditioned on the performance of institutional labor, the statute says nothing about other forms of release from the institution short of final discharge. A misconstruction of the statute may improperly curtail those other procedures when a patient refuses to perform institutional labor. Reliance on proposed section 704(3) that "[t]he provisions of this chapter shall be construed to protect and promote the basic human dignity ..." might overcome an assertion that a patient can be denied release, though not "discharge," from a mental hospital simply because he has refused to "voluntarily" engage in institutional labor. However, proposed section $728(7)$, which requires the return of personal property to a patient at the time he is "released" from the hospital, gives some indication that a distinction can be drawn between "release" and "discharge." Proposed section 736(1) should be redrafted to avoid such linedrawing. 
otherwise employ someone shall be compensated appropriately and in accordance with applicable state and federal labor laws.

(3) A resident who performs labor other than that described in subsection (2) shall be compensated an appropriate amount if an economic benefit to another person or agency results from his labor.

(4) The governing body of the facility may provide for compensation of a resident when he performs labor not goverened by subsection (2) or (3).

(5) Subsections (1), (2), and (3) shall not apply to labor of a personal housekeeping nature, nor to labor performed as a condition of residence im a small group living arrangement.

(6) One-half of any compensation paid to a resident pursuant to this section shall be exempt from collection pursuant to this act as payment for services rendered. ${ }^{272}$

Critique: The thrust of proposed sections 736 (1) and (2) is to permit institutional operations and maintenance work [heremafter "institutional labor"] by patients only if they undertake it voluntarily and and are compensated for their labor. The statutory language, however, may not achieve the desired results. For example, the statute fails to designate who decides whether the type of work to be performed is institutional labor, whether the patient has truly volunteered to perform such labor, whether the work is not inconsistent with the patient's treatment plan, and whether the time and effort to be expended on the work is excessive. Arguably, a number of persons could be called on to inake one or more of these judgments. This possible fraginentation of authority for the assignment, supervision, and evaluation of institutional labor may, in practice, result in work being assigned but neither supervised nor evaluated.

The performance of institutional labor usually occupies a substantial portion of a patient's day and may interfere with programs and activities that are therapeutically beneficial to the patient. Just as continued confinement of an individual is not appropriate simply because the is a good worker, asssignment to labor initially is not appropriate if it in any way subverts the treatment process. The statute should specify. that institutional labor is permitted only when approved by the physician or other person in charge of the patient's treatment plan and only after he has determined that such voluntary work is a desirable

272. By exempting from collection one-half of any compensation paid to a patient for labor, proposed section 736 msures that patients will receive some pay for their work and that the process does not become merely an institutional bookkeeping arrangement. The "one-half" figure was arbitrarily chosen. In Wyatt, the court exempted all compensation for work performed by patients from the costs of hospitalization. Wyatt v. Stickney, 344 F. Supp. 373, 381 (M.D. Ala. 1972). The Wyatt approach more fully achieves the laudable statutory objective. 
and appropriate part of the patient's overall treatment plan. ${ }^{273}$ The physician's decision should be recorded in the patient's clinical record together with a statement of justification. The physician should be required to evaluate-at frequent and stated intervals-the desirability of the patient's continued performance of institutional labor. ${ }^{274}$

Proposed section 736 does not indicate whether or not a patient may be compelled to perform labor which does not involve the operation and maintenance of the institution. Because section 736(1) permits institutional labor only on a voluntary basis, the statute could conceivably be construed to authorize any other labor to be ordered on a nonvoluntary basis. The court in Wyatt seems to have adopted a similar position sans statute, when it held that "[p]atients may be required to perform therapeutic tasks which do not involve the operation and maintenance of the hospital . . .."275

Requiring work as a therapy is also consistent with the limited right of a patient to decline treatment. ${ }^{276}$ Work therapy probably does not pose a danger to the physical and mental well-bemg of the patient significant enough to allow him to decline the "treatunent." Nevertheless, if institutional labor is to be permitted only if it is voluntary and an appropriate part of the individual's treatment plan, it is consistent to require that all other work meet this twofold requirement as well. As a middle ground, the statute should at least provide that the person in charge of the individual's treatunent plan may assign a patient to noninstitutional labor if it is an appropriate part of the overall treatment plan for the patient. The patient, however, should not be statutorily required to perform such work, just as a patient assigned to group therapy cannot be compelled to participate in a group therapy session.

Proposed section $736(2)$ requires that the patient be compensated "appropriately and in accordance with applicable State and federal labor laws." These laws permit a reduced remuneration for a reduced

273. Proposed section 736(1) declares that the time or effort necessary to perform institutional labor shall not be "excessive" but does not relate the concept of excessiveness to any standard. The concept should be related to the patient's treatment plan. Even 15 minutes of labor may be "excessive" for a patient who is not physically or mentally able to cope with such work assignment. At the other extreme, some outside time limit of physical and mental endurance is desirable to preclude patients from working more hours during any day than does a person working on a similar job who is not mentally ill.

274. Even in those states which define all patient labor performed under the direction of a physician as "therapeutic," inadequate supervision and evaluation has been commonly encountered. Reibman, supra note 183, at 540. A statutory provision requiring the physician to periodically evaluate the decision to authorize institutional labor may alleviate this situation.

275. Wyatt v. Stickney, 344 F. Supp. 373, 381 (M.D. Ala. 1972).

276. See the discussion in text accompanying notes 188-92 supra. 
level of performance. ${ }^{277}$ To give the word "appropriately" significance, patients should be entitled to receive either the amount of compensation required by the minimum wage law or the prevailing wage for such work given the productivity of the patient, whichever is greater.

Proposed section 736(3) permits "an appropriate amount" of compensation for noninstitutional labor that is of an economic benefit to another. There is no indication in the statute of how or by whom appropriateness is determined. Proposed section 736(4) is even more indefinite. Compensation is authorized for other labor, but there is no requirement that payment be "appropriate" for the work performed. In my opinion, all work performed under any of the provisions should be compensated in aecordance with the test proposed above for institutional labor. Since under the minimum wage law provisions lower than normal production will result in less pay than the regular minimuin wage rate, institutions should not be deterred from implementing work programs for the patients.

Finally, the statute should also secure a patient's right to contest: (1) the voluntariness of his decision to work-to the extent his voluntary choice is statutorily protected; (2) the desirability of the work as a part of his treatment plan; and (3) the amount of pay he is to receive for work performed. ${ }^{278}$

\section{Recordkeeping and Confidentiality}

If the Legislative Committee's recommendations for patients' rights are enacted, a patient's record will be important for legal as well as medical purposes. The record should be detailed, complete, and confidential. The Legislative Committee has proposed:

Sec. 746. (1) A complete record shall be kept current for each recipient of mental health services. The record shall at least include information pertinent to the services provided to the recipient, pertinent to the legal status of the recipient, required by this chapter or other provision of law, and required by rules or policies.

(2) The material in the record shall be confidential to the extent it is made confidential by section 748 .

Section 748 declares that information in the patient's record shall

277. For example, Michigan law provides:

On petition of a party in interest or on its own motion, the wage deviation board shall:

(b) Establish a suitable scale of rates for apprentices, learners, physically and mentally handicapped persons who are clearly unable to meet normal production standards, which may be less than the regular minimum wage rate for experienced and nonhandicapped workers.

Mich. Comp. LAWs. ANN. $\$ 408.387$ (1967).

278. See Part IV C of this Article infra. 
bo kept confidential and shall not be open to public inspection. ${ }^{270}$ Disclosure is permitted only to specifically authorized individuals and for specifically authorized purposes. ${ }^{280}$ The identity of the patient and other information on the patient's record is not to be disclosed unless germane to the authorized purpose. ${ }^{281}$ Section 750 then contains pro-

279. Proposed section 748(1) provides:

Information in the record of a recipient, and other information acquired in the course of providing mental health services to a recipient, shall be kept confidential and shall not be open to public inspection. The information may be disclosed outside the department, county community mental health program, or licensed private facility, whichever is the holder of the record, only in the circumstances and under the conditions set forth in this section.

280. Proposed section 748(4) provides:

When requested, information shall be disclosed:

(a) Pursuant to orders or subpoenas of a court of record, or subpoenas of the legislature, unless the information is made privileged by some provision of law.

(b) To a prosecuting attorney as necessary for him to participate in a proceeding governed by this act.

(c) To an attorney for the recipient, when the recipient has given his consent.

(d) When necessary in order to comply with another provision of law.

(e) To the department when the information is necessary in order for the department to discharge a responsibility placed upon it by law.

Proposed section $748(5)$ provides:

Information may be disclosed if the holder of the record and the recipient, his parents if he is a minor, or his legally appointed guardian consent:

(a) To providers of mental health services to the recipient.

(b) To the recipient or any other person or agency, provided that in the judgment of the holder the disclosure would not be detrimental to the recipient or others.

Proposed section $748(6)$ provides: ord:

Information may be disclosed in the discretion of the holder of the recfits.

(a) As necessary in order for the recipient to apply for or receive bene-

(b) As necessary for the purpose of outside research, evaluation, accreditation, or statistical compilation, provided that the person who is the subject of the information can be identified from the disclosed information only when such identification is essential in order to achieve the purpose for which the information is sought or when preventing such identification would clearly be impractical, but in no event when the subject of the information is likely to be harmed by such identification.

(c) To providers of mental or other health services or a public agency when there is a compelling need for disclosure based upon a substantial probability of harm to the recipient or other persons.

281. Proposed section 748(2) provides:

When information is disclosed, the identity of the individual to whom it pertains shall be protected and shall not be disclosed unless it is germane to the authorized purpose for which disclosure was sought; and, when practicable, no other information shall be disclosed unless it is germane to the authorized purpose for which disclosure was sought.

Proposed section 748(3) provides:

Any person receiving information made confidential by this section shall disclose the information to others only to the extent consistent with the authorized purpose for which the information was obtained. 
visions establishing and governing disclosure of privileged communications made to a psychiatrist or psycholgist in connection with the examination, diagnosis, or treatment of patients. ${ }^{282}$

Critique: The language of proposed section 746(1) should be compared with the extensive records requirements issued in the Wyatt case. ${ }^{283}$ The latter detailed 16 significant items to be included in every patient's record: identification data, a patient history, complaints of and about the patient, the circunistances leading to admission, a summary of each physical examination, a copy of the individual treatment plan and any modifications thereof, a summary of each periodic review of the treatment plan, a copy of the individualized post-hospitalization plan, a medication history and status, a summary of each

282. Proposed section 750 provides:

(1) For purposes of this section:

(a) "Psychiatrist" means a person licensed to practice medicine or osteopathy in Michigan, or someone under his supervision, while engaged in the examination, diagnosis, or treatment of a patient for a mental condition.

(b) "Psychologist" means a person certified as a consulting psychologist or psychologist pursuant to Act No. 257 of the Public Acts of 1959, as amended; a person with training and experience equivalent to that necessary for certification as a consulting psychologist or psychologist; or a person employed by a public agency as a psychologist; or someone under the supervision of such a person, while engaged in the examination, diagnosis, or treatment of a patient for a inental condition.

(c) "Privileged coinmunication" means a communication made to a psychiatrist or psychologist in connection with the examination, diagnosis, or treatment of a patient, or to other persons while they are participating in such examination, diagnosis, or treatment.

(2) Privileged communications shall not be disclosed in civil, criminal, legislative, or adininistrative cases or proceedings, or in proceedings preliminary to such cases or proceedings, unless the patient has waived the privilege, except in the circumstances set forth in this section.

(3) Privileged communications shall be disclosed upon request:

(a) When the privileged communication is relevant to a physical or mental condition of the patient which the patient has introduced as an element of his claim or defense in a civil or administrative case or proceeding or which, after the death of the patient, has been introduced as an element of his claim or defense by a party to a civil or administrative case or proceeding.

(b) When the privileged cominunication is relevant to a matter under consideration in a proceeding governed by this act.

(c) When the privileged communication is relevant to a matter under consideration in a proceeding to determine the legal competence of the patient or his need for a guardian.

(d) In actions, civil or criminal, against the psychiatrist or psychologist for malpractice.

(e) When the communications were made during an examination ordered by a court, prior to which the patient was informed that any communications made would not be privileged, but only with respect to the particular purpose for which the examination was ordered.

(f) When the communications were made during treatment which the patient was ordered to undergo to render hiln competent to stand trial on a criminal charge, but only with respect to issues to be determined in proceedings concerned with the competence of the patient to stand trial.

283. Wyatt v. Stickney, 344 F. Supp. 373, 385 (M.D. Ala. 1972). 
significant contact by a Qualified Mental Health Professional with the patient, a weekly summary of the patient's treatment progress, a weekly summary of the patient's work activities, orders of restrictions on visitations and communication, orders of physical restraints and isolation, a summary of extraordinary incidents involving the patient, a summary of an examination to determine whether the patient continues to require hospitalization to be conducted within 15 days of admission. Because of the importance of patient records, a specific articulation of their content, similar to the items required by Wyatt, should be adopted by statute.

\section{Enforcement of Patients' Rights}

The Legislative Committee's proposals for patients' rights generally utilize a similar framework. Each statute: (1) enumerates a basic right of institutionalized mental patients; (2) indicates the conditions required before restricting the right in an individual case; (3) authorizes a physician or other person to restriot the right when he determines that the stated condition exists; (4) requires that any decision to restrict a right be entered on the patient's record; and (5) requires the reinstatement of the right when the condition for restricting it has been removed.

To be truly protective of patients' rights, the legislation must also provide an effective complaint procedure, so that the patient may contest the validity of the decision either to restrict a right or to deny its reinstatement. At the same time, complaints must be processed in such a way as to preserve the therapeutic relationship existing between patients and treating personnel.

The Legislative Committee has proposed:

Sec. 752. (1) Providers of mental health services to recipients shall adopt official policies and procedures in writing as necessary to implement this chapter.

(2) The policies and procedures may amplify, particularize, or expand the rights guaranteed to recipients by this chapter.

(3) The policies and procedures sliall provide a simple mechanism for recipients and others to report apparent violations of this chapter; shall provide a system for determining whether in fact violations liave occurred; and shall ensure that firm and fair disciplinary and appropriate remedial action is taken in the event of a violation.

Sec. 754. The department, eacli county community mental health program, and any facility operated by a political subdivision of the state separate from a county cominunity mental health program shall establish an office subordinate only to the chief official of the agency establishing it. The office shall receive reports of and may investigate apparent violations of the rights guaranteed by this 
chapter, may act to resolve disputes relating to apparent violations, may act on behalf of recipients of mental health services to obtain remedy for any apparent violations, and shall otherwise endeavor to safeguard the rights guaranteed by this chapter.

Critique: The adoption of a simple system for reponting, factfinding, and remedying violations, required by proposed section 752 (3), and the establishment of a "patients' rights office" within each treating agency, required by proposed section 754, are not objectionable in and of themselves. These proposals, however, do not sufficiently protect patients' rights.

Alternatives have been suggested. The Pennsylvania "right to treatment" bills contained a proposal for a Patient Treatment Review Board consisting of two licensed psyohiatrists, two licensed medical practitioners, and one attorney. ${ }^{284}$ Members of the board were to serve on a full-time basis, ${ }^{285}$ independent of existing state agencies. ${ }^{286}$ The board was "to receive, hear and investigate petitions filed on behalf of patients who allege that they are not receiving minimum standards of treatment. . . ."287 In Wyatt, the court created a human rights committee, composed of seven laypersons, for each mental institution. In addition to reviewing all research proposals, each committee is charged with advising and assisting patients who allege that their legal rights have been infringed. ${ }^{288}$ These suggestions may be more protective of patients' rights than the Legislative Committee's proposals, but in my opinion they too are madequate.

Whether mentally ill or not, an individual in society who has a question or problem concerning his legal rights normally consults a lawyer. For a number of reasons, however, attorneys have not as yet become involved to any great extent with legal problems of patients confined in mental hospitals. Patients' rights have generally not been clarified by statute. Also, due to a lack of sophistication or mental competence, patients may not seek the help of lawyers to contest alleged violations of their rights. Additionally, lawyers lack expertise in this neglected area, and liandling legal problems of mental patients is often financially unprofitable to an attorney. A lawyer may find that the occasional mental patient client, whom he must visit in an institution rather than in his own office, consumes too much of his working time over apparently inconsequential though complex matters.

Commentators may be reluctant to call for an extended use of an attorney in the institutional setting because of the attorney's traditionally

284. E.g., S.B. 158, Pa. Gen. Assembly, 1969 Sess. $\$ 6($ a).

285. Id. $\S 6(\mathrm{~b})$.

286. Id. § $6(\mathrm{a})$.

287. $1 d$. $\S 6(\mathrm{~d})$.

288. Wyatt v. Stickney, 344 F. Supp. 373, 376 (M.D. Ala. 1972). 
adversarial role. His advocacy is viewed as counter-productive to the establishment of the trusting attitude needed for effective treatment of the patient. However, New York's recent experience with specialized attorneys in the institutions is encouraging and suggests a workable and effective approach to the problem of enforcing the in-hospital rights of inental patients.

In 1965 , new laws modifying mental hospitalization procedures went into effect in New York. ${ }^{289}$ The Mental Health Information Service $^{290}$ [hereinafter MHIS] was created by statute in each of the state's four Judicial Departments. Responsible to the Appellate Division of each Department, the MHIS is staffed primarily by lawyers. Its function is to review the status of mvoluntary patients, to inform them of their rights under the law, including their rights to be represented by legal counsel and to seek independent medical opinion, to assenble information for the court whenever a hearing is requested, and to advise patients when they seek aid.

The MHIS has generally proved invaluable in aiding patients without unduly hampering administration of the institutions. Contrary to the fears of some hospital personnel, the presence of specially trained mental health lawyers in the institutions has resulted in less conflict and less bitigation. Lawyers who work full-time on onental patients' problems and who contimually observe the difficulties involved in working within and administering the institutions develop an expertise which avoids rather than proinotes litigation. Only in the most extreme situations do competent attorneys employ the formalized relief of judicial intervention. The desire of MHIS workers to reach a negotiated settleinent of a dispute to the satisfaction of both the psychiatrist and the patient has been attested to repeatedly. ${ }^{201}$

The New York MHIS deals primarily with legal problems involved in the civil commitment process. Suoh an agency, however, could easily be assigned the role of counseling patients and insuring protection of their legal interests in the institutions. ${ }^{292}$

289. N.Y. Sess. Laws 1964, ch. 738. These laws have been revised and recodified as N.Y. MENT. HYG. LAW $§ \S 31.01-31.47$ (McKinney Supp. 1973).

290. N.Y. MEnt. HYg. LAW $\$ 29.09$ (McKinney Supp. 1973).

291. Gupta, New York's Mental Health Information Service: An Experiment in Due Process, 25 Rutgers L. REv. 405 (1971); Rosensweig, Compulsory Hospitalization of the Mentally Ill, 61 AM. J. Public Health 121, 123-24 (Jan. 1971); Zitrin, Herman \& Kumasaka, New York's Mental Hygiene Law-A Preliminary Evaluation, 54 MENTAL HYGIENE 28, 33-34 (Jan. 1970).

292. Arguably, legal representation for prospective and actual mental patients could be encompassed within existing legal aid programs. However, the potentially large number of cases involved, the need for frequent, if not constant surveillance of the inpatient situation, and the desirability of developing lawyer expertise in resolving conflicts between patients and treating personnel suggest that the traditional legal aid approach may not offer the optimum solution. See also 1970 Hearings, supra note 47, 
I propose the following statute:

Sec. 000 (1) The Mental Patients' Legal Assistance Service is created within the office of the court administrator. ${ }^{293}$

(2) The director of the Service shall be an attorney licensed to practice law in this state and shall be appointed by and serve at the pleasure of the Supreme Court of Michigan.

(3) The director shall appoimt such assistants and supporting personnel as shall be necessary to perform the duties inposed on the Service by this Article.

(4) (a) The salaries of the Service personnel shall be established by the Supreme Court.

(b) Service personnel shall be reimbursed for their reasonable actual and necessary expenses by the state treasury upon the warrant of the State Treasurer.

(c) Within appropriations provided by law, the Department of Administration shall provide the Service with suitable space and equipinent. The Departinent of Mental Health shall provide office and conference room space at each of its facilities upon the reasonable request of the director of the Service.

(5) The Mental Patients' Legal Assistance Service shall perform the following duties:

(a) Counsel and represent as attorney any individual alleged to be a person requiring hospitalization in any hearing conducted im accordance with the provisions of this Act;

(b) Conduct any appeal as permitted by law of any court order or decision made in accordance with the provisions of this Act;

(c) Inform and advise all patients of their legal rights;

(d) Study and review patients' records to determine whether patients' rights are being observed;

(e) Investigate any violations of rights which appear on patients' records and any and all other violations which are complained of or observed;

at 286 (statement of Bruce J. Ennis) ("Inexperienced attorneys cannot adequately represent mental patients.").

293. The Michigan Constitution requires that "[a]ll executive and administrative offices, agencies and instrumentalities of the executive branch of state government and their respective functions, powers and duties . . . shall be allocated by law among and within not more than 20 principal departments." Mich. Comp. LAws ANN. CoNsT. Art. 5, $\$ 2$ (1967). Since these 20 principal departments have already been established, a proposed Mental Patients' Legal Assistance Service cannot be established as a separate executive agency. Establishing the Service as an office within the Department of Mental Health or Office of the Attorney General may compromise the independence that is essential to the proper functioning of the Service. Under such circumstances, it seems appropriate to recommend that the Mental Patients' Legal Assistance Service be placed within the office of the Court Administrator of the Supreme Court of Michigan. In other jurisdictions, consideration should be given to establishing such a patients' service as an independent executive agency. 
(f) Determine whether a patient's voluntary and informed consent has been obtained for any surgery, electroconvulsive therapy or other procedure intended to produce convulsions or coma, experimental research project, hazardous procedure, or other therapy requiring patient consent;

(g) Act informally to correct any violations of patients' rights;

(h) Counsel and represent patients in court in any legal dispute in situations where Service personnel determine that a right has been violated.

(6) Whenever any individual alleged to be a person requiring hospitalization or any patient is entitled to legal representation, he is to be informed by the Service that it will provide such legal representation or that he has the option of obtaining counsel of his own choosing.

(7) The Service inay represent both indigent and non-indigent individuals and shall receive appropriate compensation. All moneys received as compensation shall be accounted for and returned to the State Treasury. 